NBER WORKING PAPER SERIES

\title{
DISAGREEMENT ABOUT INFLATION EXPECTATIONS
}

\author{
N. Gregory Mankiw \\ Ricardo Reis \\ Justin Wolfers \\ Working Paper 9796 \\ http://www.nber.org/papers/w9796
}

\section{NATIONAL BUREAU OF ECONOMIC RESEARCH 1050 Massachusetts Avenue Cambridge, MA 02138}

June 2003

We would like to thank Richard Curtin and Guhan Venkatu for help with data sources and Simon Gilchrist, Robert King and John Williams for their comments. Doug Geyser and Cameron Shelton provided research assistance. Reis is grateful to the Fundacao Ciencia e Tecnologia, Praxis XXI, for financial support. The views expressed herein are those of the authors and not necessarily those of the National Bureau of Economic Research.

(C2003 by N. Gregory Mankiw, Ricardo Reis, and Justin Wolfers. All rights reserved. Short sections of text not to exceed two paragraphs, may be quoted without explicit permission provided that full credit including (C) notice, is given to the source. 
Disagreement about Inflation Expectations

N. Gregory Mankiw, Ricardo Reis, and Justin Wolfers

NBER Working Paper No. 9796

June 2003

JEL No. E3, D8, E0, E1

\begin{abstract}
$\underline{\text { ABSTRACT }}$
Analyzing 50 years of inflation expectations data from several sources, we document substantial disagreement among both consumers and professional economists about expected future inflation. Moreover, this disagreement shows substantial variation through time, moving with inflation, the absolute value of the change in inflation, and relative price variability. We argue that a satisfactory model of economic dynamics must speak to these important business cycle moments. Noting that most macroeconomic models do not endogenously generate disagreement, we show that a simple "sticky-information" model broadly matches many of these facts. Moreover, the sticky-information model is consistent with other observed departures of inflation expectations from full rationality, including autocorrelated forecast errors and insufficient sensitivity to recent macroeconomic news.
\end{abstract}

\author{
N. Gregory Mankiw \\ Department of Economics \\ Harvard University \\ Littauer 223 \\ Cambridge, MA 02138 \\ and NBER \\ ngmankiw@harvard.edu
}

$\begin{array}{ll}\text { Ricardo Reis } & \text { Justin Wolfers } \\ \text { Department of Economics } & \text { Graduate School of Business } \\ \text { Harvard University } & \text { Stanford University } \\ \text { Cambridge, MA 02138 } & \text { 518 Memorial Way } \\ \text { reis@fas.harvard.edu } & \text { Stanford, CA 94305 } \\ & \text { and NBER } \\ & \text { jwolfers@stanford.edu }\end{array}$

Ricardo Reis

Harvard University

Cambridge, MA 02138 


\section{INTRODUCTION}

At least since Milton Friedman's renowned presidential address to the American Economic Association in 1968, expected inflation has played a central role in the analysis of monetary policy and the business cycle. How much expectations matter, whether they are adaptive or rational, how quickly they respond to changes in the policy regime, and many related issues have generated heated debate and numerous research studies. Yet throughout this time, one obvious fact is routinely ignored: Not everyone has the same expectation.

This oversight is probably explained by the fact that, in much standard theory, there is no room for disagreement. In many (though not all) textbook macroeconomic models, people share a common information set and form expectations conditional on that information. That is, we often assume that everyone has the same expectation because our models say they should.

The data easily rejects this assumption. Anyone who has looked at survey data on expectations, either of the general public or of professional forecasters, can attest that disagreement is substantial. For example, as of December 2002, the interquartile range of inflation expectations for 2003 among economists goes from $1 \frac{1 / 2}{2}$ percent to $2 \frac{1}{2}$ percent. Among the general public, the interquartile range of expected inflation goes from 0 percent to 5 percent.

This paper takes as its starting point the notion that this disagreement about expectations is itself an interesting variable for students of monetary policy and the business cycle. We document the extent of this disagreement and show that it varies over 
time. More important, disagreement about expected inflation moves together with the other aggregate variables that are more commonly of interest to economists. This fact raises the possibility that disagreement may be a key to macroeconomic dynamics.

A recent macroeconomic model that has disagreement at its heart is the stickyinformation model proposed by Mankiw and Reis (2002). In this model, economic agents update their expectations only periodically because of costs of collecting and processing information. We investigate whether this model is capable of predicting the extent of disagreement that we observe in the survey data, as well as its evolution over time.

The paper is organized as follows. Section II discusses the survey data on expected inflation that will form the heart of this paper. Section III offers a brief and selective summary of what is known from previous studies of survey measures of expected inflation, replicating the main findings. Section IV presents an exploratory analysis of the data on disagreement, documenting its empirical relationship to other macroeconomic variables. Section V considers what economic theories of inflation and the business cycle might say about the extent of disagreement. It formally tests the predictions of one such theory-the "sticky information" model of Mankiw and Reis (2002). Section VI compares theory and evidence from the Volcker disinflation. Section VII concludes. 


\section{INFLATION EXPECTATIONS}

Most macroeconomic models argue that inflation expectations are a crucial factor in the inflation process. Yet the nature of these expectations - in the sense of precisely stating whose expectations, over which prices, and over what horizon-is not always discussed with precision. These are crucial issues for measurement.

The expectations of wage and price-setters are probably the most relevant. Yet it is not clear just who these people are. As such, we analyze data from three sources. The Michigan Survey of Consumer Attitudes and Behavior surveys a cross-section of the population on their expectations over the next year. The Livingston Survey and the Survey of Professional Forecasters (SPF) covers more sophisticated analysts economists working in industry and professional forecasters, respectively. Table 1 provides some basic detail about the structure of these three surveys. ${ }^{1}$

\footnotetext{
${ }^{1}$ For further detail on the Michigan survey, the Livingston survey and the SPF, see Curtin (1996), Croushore (1997) and Croushore (1993), respectively.
} 
Table 1: Surveys of Inflation Expectations

\begin{tabular}{|c|c|c|c|}
\hline & Michigan Survey & Livingston Survey & $\begin{array}{l}\text { Survey of } \\
\text { Professional } \\
\text { Forecasters } \\
\end{array}$ \\
\hline $\begin{array}{l}\text { Survey } \\
\text { population }\end{array}$ & $\begin{array}{l}\text { Cross-section of the } \\
\text { general public. }\end{array}$ & $\begin{array}{l}\text { Academic, business, } \\
\text { finance, market and } \\
\text { labor economists. }\end{array}$ & Market economists. \\
\hline $\begin{array}{l}\text { Survey } \\
\text { Organization }\end{array}$ & $\begin{array}{l}\text { Survey Research } \\
\text { Center, University of } \\
\text { Michigan. }\end{array}$ & $\begin{array}{l}\text { Originally Joseph } \\
\text { Livingston an economic } \\
\text { journalist. Currently } \\
\text { the Philadelphia Fed. }\end{array}$ & $\begin{array}{l}\text { Originally } \\
\text { ASA/NBER, } \\
\text { currently the } \\
\text { Philadelphia Fed. }\end{array}$ \\
\hline $\begin{array}{l}\text { Average } \\
\text { number of } \\
\text { respondents }\end{array}$ & $\begin{array}{l}\text { Roughly } 1000-3000 \\
\text { per quarter to } 1977 \text {, } \\
\text { then } 500-700 \text { per } \\
\text { month to present. }\end{array}$ & $\begin{array}{l}48 \text { per survey. } \\
\text { (Varies from 14-63.) }\end{array}$ & $\begin{array}{l}34 \text { per survey } \\
\text { (Varies from 9-83.) }\end{array}$ \\
\hline Starting date & $\begin{array}{l}\text { Qualitative questions: } \\
\text { 1946 Q1.\# } \\
\text { Quantitative responses: } \\
\text { January } 1978 .\end{array}$ & $\begin{array}{l}\text { 1946, First half. } \\
\text { (But the early data is } \\
\text { unreliable.) }\end{array}$ & $\begin{array}{l}\text { GDP Deflator: } \\
\text { 1968, Q4. } \\
\text { CPI inflation: } \\
\text { 1981, Q3. }\end{array}$ \\
\hline Periodicity & $\begin{array}{l}\text { Most quarters from } \\
1947 \text { Q1 to } 1977 \text { Q4. } \\
\text { Every month from } \\
\text { January } 1978 .\end{array}$ & Semi-annual. & Quarterly. \\
\hline $\begin{array}{l}\text { Inflation } \\
\text { Expectation }\end{array}$ & $\begin{array}{l}\text { Expected change in } \\
\text { prices over the next } 12 \\
\text { months. }\end{array}$ & $\begin{array}{l}\text { Consumer Price Index } \\
\text { (this quarter, in } 2 \\
\text { quarters, in } 4 \text { quarters). }\end{array}$ & $\begin{array}{l}\text { GDP deflator level } \\
\text { Quarterly CPI levels } \\
\text { (6 quarters). }\end{array}$ \\
\hline
\end{tabular}

Notes: ${ }^{\#}$ Our quantitative work will focus on the period from 1954 onward.

Although we have three sources of inflation expectations data, throughout this paper we will focus on four, and occasionally five, series. Most papers analyzing the Michigan data cover only the period since 1978 in which these data have been collected monthly (on a relatively consistent basis), and respondents were asked to state their precise quantitative inflation expectation. However, the Michigan Survey of Consumer Attitudes and Behaviors has been conducted quarterly since 1946, even though for the first twenty 
years respondents were asked only whether they expected prices to rise, fall, or stay the same. We have put substantial effort into constructing a consistent quarterly time series for the central tendency and dispersion of inflation expectations through time since 1948. We construct these data by assuming that discrete responses to whether prices are expected to rise, remain the same, or fall over the next year reflect underlying continuous expectations drawn from a normal distribution, with a possibly time-varying mean and standard deviation. ${ }^{2}$ We will refer to these constructed data as the "Michigan experimental" series.

Our analysis of the Survey of Professional Forecasters will occasionally switch between our preferred series, which is the longer time series of forecasts focusing on the GDP deflator (starting in 1968, Q4), and the shorter CPI series (which only begins in 1981, Q3).

Figure 1 graphs our inflation expectations data (where the horizontal axis refers to expectations at the endpoint of the relevant forecast horizon, rather than at the time the forecast was made). Two striking features emerge from these plots. First, each series yields relatively accurate inflation forecasts. And second, despite the different populations being surveyed, they all tell a somewhat similar story.

\footnotetext{
${ }^{2}$ Construction of this experimental series is detailed in the appendix, and we have published these data online at: www.stanford.edu/people/jwolfers.
} 
Figure 1: Inflation Expectations and the Inflation Rate

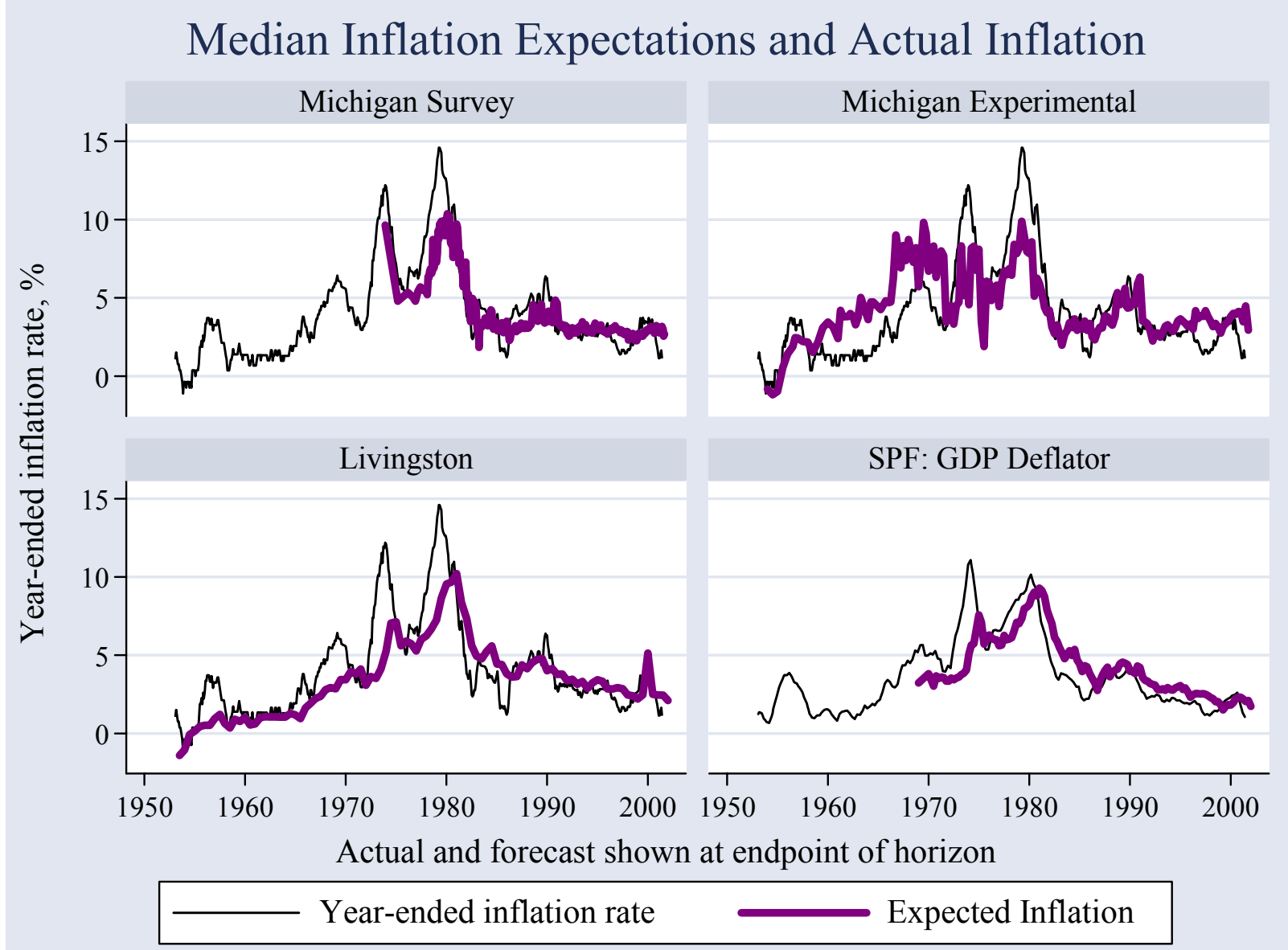

By simple measures of forecast accuracy, all three surveys appear to be quite useful. Table 2 shows two common measures of forecast accuracy: the square root of the average squared error (RMSE) and the mean absolute error (MAE). In each case we report the accuracy of the median expectation in each survey, both over their maximal samples, and for a common sample (September 1982-March 2002). 
Table 2: Inflation Forecast Errors

\begin{tabular}{|c|c|c|c|c|c|}
\hline & Michigan & $\begin{array}{l}\text { Michigan } \\
\text { Experimental }\end{array}$ & Livingston & $\begin{array}{l}\text { SPF - GDP } \\
\text { Deflator }\end{array}$ & SPF - CPI \\
\hline \multicolumn{6}{|c|}{ Panel A: Maximal Sample } \\
\hline Sample & $\begin{array}{l}\text { Nov. 1974- } \\
\text { May } 2002\end{array}$ & $\begin{array}{c}1954, \mathrm{Q} 4- \\
2002, \mathrm{Q} 1\end{array}$ & $\begin{array}{l}\text { 1954, H1- } \\
2001, \text { H2 }\end{array}$ & $\begin{array}{c}1969, Q^{4}- \\
2002, Q 1\end{array}$ & $\begin{array}{c}1982, Q 3- \\
2002, Q 1\end{array}$ \\
\hline RMSE & $1.65 \%$ & $2.32 \%$ & $1.99 \%$ & $1.62 \%$ & $1.29 \%$ \\
\hline MAE & $1.17 \%$ & $1.77 \%$ & $1.38 \%$ & $1.22 \%$ & $0.97 \%$ \\
\hline \multicolumn{6}{|c|}{ Panel B: Common time period (September 1982-March 2002) } \\
\hline RMSE & $1.07 \%$ & $1.24 \%$ & $1.28 \%$ & $1.10 \%$ & $1.29 \%$ \\
\hline MAE & $0.85 \%$ & $0.95 \%$ & $0.97 \%$ & $0.91 \%$ & $0.97 \%$ \\
\hline
\end{tabular}

Panel A suggests that inflation expectations are relatively accurate. Moreover, as the group making the forecast becomes increasingly sophisticated, forecast accuracy appears to improve. However, Panel B suggests that these differences across groups largely reflect the different periods over which each survey has been conducted. For the common sample that all five measures have been available, they are all approximately equally accurate.

Of course, these results reflect the fact that these surveys have a similar central tendency, and this reveals as much as it hides. Figure 2 presents simple histograms of expected inflation for the coming year as of December 2002. 
Figure 2: Distribution of Inflation Expectations

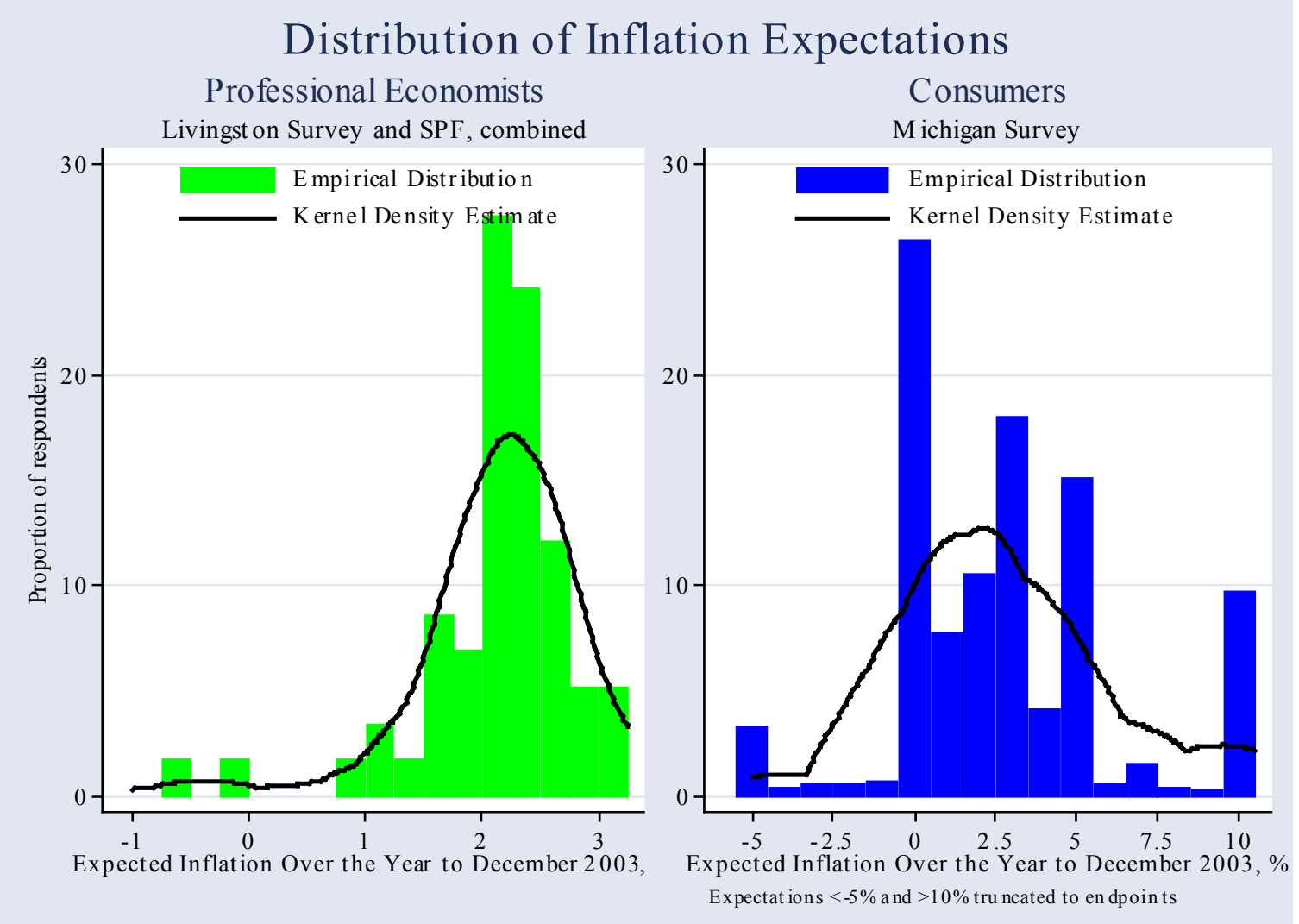

Here the differences among these populations become starker. The left panel pools responses from the two surveys of economists and shows some agreement on expectations, with most respondents expecting inflation in the $1 \frac{1 / 2-3}{2}$ percent range. The survey of consumers reveals substantially greater disagreement. The interquartile range of consumer expectations stretches from 0 to 5 percent and this distribution shows quite long tails, with 5 percent of the population expecting deflation, while 10 percent expect inflation of at least 10 percent. These long tails are a feature throughout our sample, and are not a particular reflection of present circumstances. Our judgment (following Curtin, 1996) is that these extreme observations are not particularly informative, and so we focus on the median and interquartile range as the relevant indicators of central tendency and disagreement, respectively. 
The extent of disagreement within each of these surveys varies dramatically over time. Figure 3 shows the interquartile range over time for each of our inflation expectations series. 
Figure 3. Disagreement Through Time

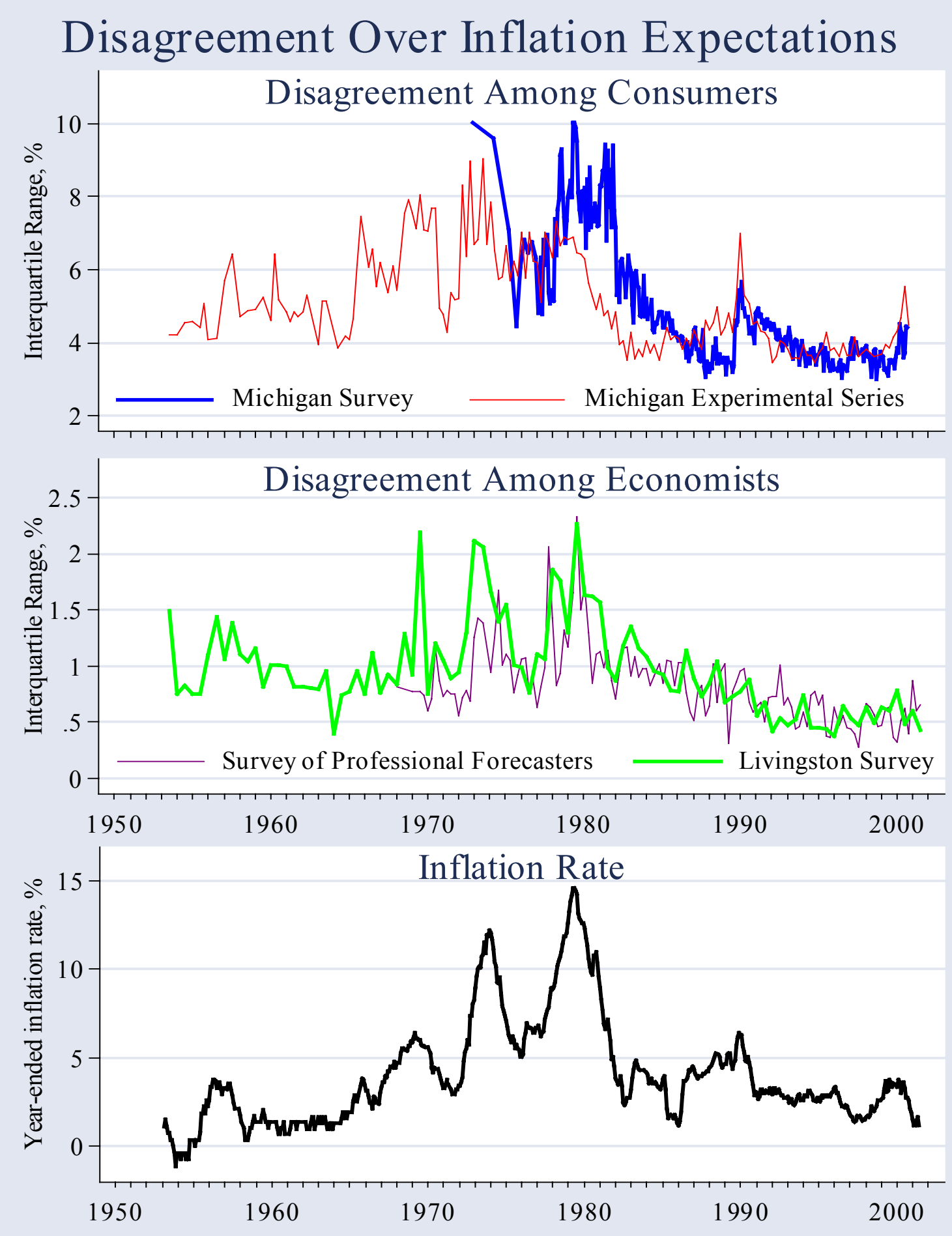

Date reflects when the forecast is made

A particularly interesting feature of these data is that disagreement among professional forecasters rises and falls with disagreement among economists and the 
general public. Table 3 confirms that all of our series show substantial co-movement. This table focuses on quarterly data - by averaging the monthly Michigan numbers, and linearly interpolating the semi-annual Livingston numbers. The top panel shows correlation coefficients among these quarterly estimates. The bottom panel shows correlation coefficients across a smoothed version of the data (a 5-quarter centered moving average of the interquartile range). While the high frequency data exhibit reasonable correlation, this co-movement is particularly strong when focusing on lower frequency movements. (The experimental Michigan data shows a somewhat weaker correlation, particularly in the high frequency data. This probably reflects measurement error, caused by the fact that these estimates rely heavily on the proportion of the sample expecting price declines - a small and imprecisely estimated fraction of the population.) 
Table 3: Disagreement Through Time - Correlation Across Surveys ${ }^{(a)}$

\begin{tabular}{|c|c|c|c|c|c|}
\hline & Michigan & $\begin{array}{l}\text { Michigan } \\
\text { Experimental }\end{array}$ & Livingston & $\begin{array}{l}\text { SPF-GDP } \\
\text { deflator }\end{array}$ & SPF-CPI \\
\hline \multicolumn{6}{|c|}{ Panel A: Actual quarterly data } \\
\hline Michigan & 1.000 & & & & \\
\hline Michigan & 0.682 & 1.000 & & & \\
\hline Livingston & 0.809 & 0.391 & 1.000 & & \\
\hline $\begin{array}{l}\text { SPF-GDP } \\
\text { deflator }\end{array}$ & 0.700 & 0.502 & 0.712 & 1.000 & \\
\hline SPF-CPI & 0.667 & 0.231 & 0.702 & 0.688 & 1.000 \\
\hline \multicolumn{6}{|c|}{ Panel B: 5 quarter centered moving averages } \\
\hline Michigan & 1.000 & & & & \\
\hline $\begin{array}{l}\text { Michigan } \\
\text { experimental }\end{array}$ & 0.729 & 1.000 & & & \\
\hline Livingston & 0.869 & 0.813 & 1.000 & & \\
\hline $\begin{array}{l}\text { SPF-GDP } \\
\text { deflator }\end{array}$ & 0.850 & 0.690 & 0.889 & 1.000 & \\
\hline SPF-CPI & 0.868 & 0.308 & 0.886 & 0.865 & 1.000 \\
\hline
\end{tabular}

a) Underlying data are quarterly - created by taking averages of monthly Michigan data, and linearly interpolating half-yearly Livingston data.

A final source of data on disagreement comes from the range of forecasts within the FOMC, as published biannually since 1979 in Humphrey-Hawkins testimony. ${ }^{3}$ Unfortunately individual-level data are not released, so we simply look to describe the broad pattern of disagreement among these experts. Figure 4 shows that there exists a rough (and statistically significant) correspondence between disagreement among policymakers and that among professional economists. The correlation of the range of FOMC forecasts with the interquartile range of the Livingston population is either 0.34 , 0.54 and 0.63 , depending on which of the three available FOMC forecasts we use. 
Interestingly, while disagreement among Fed-watchers rose during the Volcker disinflation, the range of inflation forecasts within the Fed remained largely constant the correlation between disagreement among FOMC members and disagreement among professional forecasters is substantially higher after 1982.

Figure 4: Disagreement Among the FOMC

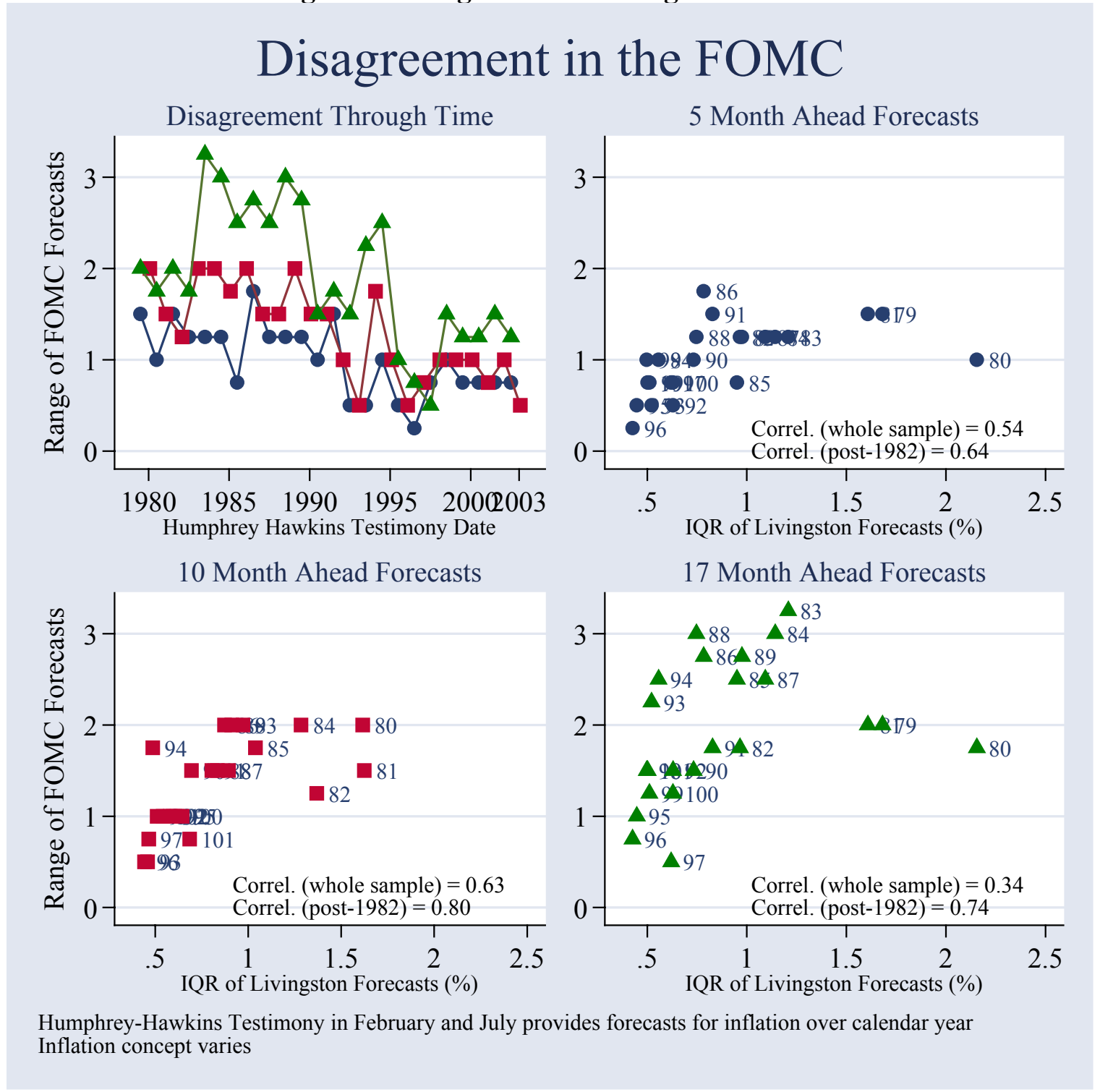

\footnotetext{
${ }^{3}$ We are grateful to Simon Gilchrist for suggesting this analysis to us. Data were drawn from Gavin (2003) and updated using recent testimony published at http://www.federalreserve.gov/boarddocs/hh/.
} 
We believe that we have now established three important patterns in the data. First, there is substantial disagreement within both naïve and expert populations about the expected future path of inflation. Second, there are larger levels of disagreement between consumers than that between experts. And third, even though professional forecasters, economists and the general population show different degrees of disagreement, this disagreement tends to exhibit similar time series patterns, albeit of a different amplitude. One would therefore expect to find that the underlying causes behind this disagreement are similar across all three datasets.

\section{The CENTRAL TENDENCY OF INFLATION EXPECTATIONS}

Most studies analyzing inflation expectations data have explored whether empirical estimates are consistent with rational expectations. The rational expectations hypothesis has strong implications for the time series of expectations data, most of which can be stated in terms of forecast efficiency. More specifically, rational expectations implies (statistically) efficient forecasting, and efficient forecasts do not yield predictable errors. We now turn to reviewing the tests of rationality commonly found in the literature, and to providing complementary evidence based on the estimates of median inflation expectations in our sample. ${ }^{4}$

The simplest test of efficiency is a test for bias: are inflation expectations centered on the right value? Panel A of Table 4 reports these results, regressing expectation errors on a constant. Median forecasts have tended to under-predict inflation in two of the four

\footnotetext{
${ }^{4}$ Thomas (1999) provides a survey of this literature.
} 
data series, and this divergence is statistically significant; that said, the magnitude of this bias is small. ${ }^{5}$

Panel B tests whether there is information in these inflation forecasts themselves that can be used to predict forecasting errors, by regressing the forecast error on a constant and the median inflation expectation. ${ }^{6}$ Under the null of rationality, these regressions should have no predictive power. Both the Michigan and Livingston series can reject a rationality null on this score, while the other two series are consistent with this (rather modest) requirement of rationality.

Panel C exploits a time-series implication of rationality, asking whether today's errors can be forecasted based on yesterday's errors. In these tests, we regress this year's forecast error on the realized error over the previous year. Evidence of autocorrelation suggests that there is information in last year's forecast errors that is not being exploited in generating this year's forecast, violating the rationality null. We find robust evidence of autocorrelated forecast errors in all surveys. When interpreting these coefficients, note that they reflect the extent to which errors made a year ago persist in today's forecast. We find that on average around half of the error remains in the median forecast. One might object that last year's forecast error may not yet be fully revealed by the time this year's forecast is made, because inflation data are only published with one month lag. Experimenting with slightly longer lags does not change these results significantly. ${ }^{7}$

\footnotetext{
${ }^{5}$ Note that the construction of the Michigan experimental data makes the finding of bias unlikely for that series.

${ }^{6}$ Some readers may be more used to seeing regressions of the form: $\pi_{t}=a+b E_{t-12} \pi_{t}$, where the test for rationality is a joint test of $a=0$ and $b=1$. To see that our tests are equivalent, simply rewrite

$\pi_{t}-E_{t-12} \pi_{t}=a+(1-b) E_{t-12} \pi_{t}$ and it can be seen that a test of $a=0$ and $b=1$ translates into a test that the constant and slope coefficient in this equation are both zero.

${ }^{7}$ Interestingly, repeating this analysis with mean rather than median expectations yields weaker results.
} 
Finally, Panel D asks whether inflation expectations take sufficient account of publicly available information. We regress forecast errors on recent macroeconomic data. Specifically, we analyze the inflation rate, the Treasury bill rate, and the unemployment rate measured one month prior to the forecast, because these data are likely to be the most recent published data when forecasts were made. We also control for the forecast itself, thereby nesting the specification in Panel B. One might object that using real-time data would better reflect the information available when forecasts were made; we chose these three indicators precisely because they are subject to only minor revisions. Across the three different pieces of macroeconomic information and all four surveys, we often find statistical evidence that agents are not fully incorporating this information in their inflation expectations. Simple bivariate regressions (not shown) yield a qualitatively similar pattern of responses. The advantage of the multivariate regression is that we can perform an F-test of the joint significance of the lagged inflation, interest rates and unemployment rates in predicting forecast errors. In each case the macroeconomic data are overwhelmingly jointly statistically significant, suggesting that median inflation expectations do not adequately take account of recent available information. Note that these findings do not depend on whether we condition on the forecast of inflation. 
Table 4: Tests of Forecast Rationality: Median Inflation Expectations

\begin{tabular}{|c|c|c|c|c|}
\hline & Michigan & $\begin{array}{l}\text { Michigan- } \\
\text { Experimental }\end{array}$ & Livingston & $\begin{array}{l}\text { SPF } \\
\text { (GDP deflator) }\end{array}$ \\
\hline \multicolumn{5}{|c|}{ Panel A: Testing for Bias: $\pi_{t}-E_{t-12} \pi_{t}=\alpha$} \\
\hline $\begin{array}{l}\alpha: \text { Mean Error } \\
\text { (Constant only) }\end{array}$ & $\begin{array}{l}0.42 \% \\
(0.29)\end{array}$ & $\begin{array}{l}-0.09 \% \\
(0.34)\end{array}$ & $\begin{array}{l}0.63 \%^{* *} \\
(0.30)\end{array}$ & $\begin{array}{l}-0.02 \% \\
(0.29)\end{array}$ \\
\hline \multicolumn{5}{|c|}{ Panel B: Is Information in the Forecast Fully Exploited? $\pi_{t}-E_{t-12} \pi_{t}=\alpha+\beta E_{t-12} \pi_{t}$} \\
\hline \multirow[t]{2}{*}{$\beta: E_{t-12}\left[\pi_{t}\right]$} & $0.349^{* *}$ & -0.060 & 0.011 & 0.026 \\
\hline & $(.161)$ & $(.207)$ & $(.142)$ & $(.128)$ \\
\hline \multirow[t]{2}{*}{$\alpha:$ Constant } & $-1.016 \% *$ & $-0.182 \%$ & $0.595 \%$ & $-0.132 \%$ \\
\hline & $(.534)$ & $(.721)$ & $(.371)$ & $(.530)$ \\
\hline Adj. $\mathbf{R}^{2}$ & 0.197 & -0.003 & -0.011 & -0.007 \\
\hline $\begin{array}{l}\text { Reject Eff.? } \alpha=\beta=0 \\
\text { (p-value) }\end{array}$ & $\begin{array}{l}\text { Yes } \\
(p=0.088)\end{array}$ & $\begin{array}{l}\text { No } \\
(p=0.956)\end{array}$ & $\begin{array}{l}\text { Yes } \\
(p=0.028)\end{array}$ & $\begin{array}{l}\text { No } \\
(p=0.969)\end{array}$ \\
\hline \multicolumn{5}{|c|}{ Panel C: Are Forecasting Errors Persistent? $\pi_{t}-E_{t-12} \pi_{t}=\alpha+\beta\left(\pi_{t-12}-E_{t-24} \pi_{t-12}\right)$} \\
\hline \multirow[t]{2}{*}{$\beta: \pi_{t-12}-E_{t-24}\left[\pi_{t-12}\right]$} & $0.371^{* *}$ & $.580^{* * *}$ & $0.490^{* * * *}$ & $0.640^{* * *}$ \\
\hline & $(0.158)$ & $(0.115)$ & $(0.132)$ & $(0.224)$ \\
\hline \multirow[t]{2}{*}{$\alpha:$ Constant } & $0.096 \%$ & $0.005 \%$ & $0.302 \%$ & $-0.032 \%$ \\
\hline & $(0.183)$ & $(0.239)$ & $(0.210)$ & $(0.223)$ \\
\hline Adj. $\mathbf{R}^{2}$ & 0.164 & 0.334 & 0.231 & 0.375 \\
\hline \multicolumn{5}{|c|}{ Panel D: Are Macroeconomic data fully exploited? } \\
\hline \multirow[t]{2}{*}{$\alpha:$ Constant } & $-0.816 \%$ & $0.242 \%$ & $4.424 \%{ }^{* *}$ & $3.566 \%{ }^{* * *}$ \\
\hline & $(0.975)$ & $(1.143)$ & $(0.985)$ & $(0.970)$ \\
\hline \multirow[t]{2}{*}{$\beta: \mathbf{E}_{t-12}\left[\pi_{t}\right]$} & $0.801^{* * *}$ & $-0.554^{* * *}$ & 0.295 & 0.287 \\
\hline & $(0.257)$ & $(0.165)$ & $(0.283)$ & $(0.308)$ \\
\hline \multirow[t]{2}{*}{$\gamma:$ Inflation $_{\mathrm{t}-13}$} & $-0.218^{*}$ & $0.610^{* * *}$ & 0.205 & 0.200 \\
\hline & $(0.121)$ & $(0.106)$ & $(0.145)$ & $(0.190)$ \\
\hline \multirow[t]{2}{*}{ к: Treasury Bill ${ }_{t-13}$} & $-0.165^{* *}$ & -0.024 & $-0.319^{* * *}$ & $-0.321^{* * * *}$ \\
\hline & $(0.085)$ & $(0.102)$ & $(0.106)$ & $(0.079)$ \\
\hline \multirow[t]{2}{*}{$\delta:$ Unemployment $_{\mathrm{t}-13}$} & 0.017 & -0.063 & $-0.675^{* * *}$ & $-0.593^{* * *}$ \\
\hline & $(0.126)$ & $(0.156)$ & $(0.175)$ & $(0.150)$ \\
\hline Reject Eff.? $\gamma=\kappa=\delta=0$ & Yes & Yes & Yes & Yes \\
\hline (p-value) & $(p=0.049)$ & $(p=0.000)$ & $(p=0.000)$ & $(p=0.000)$ \\
\hline Adj. $R^{2}$ & 0.293 & 0.382 & 0.306 & 0.407 \\
\hline Sample & Nov. $1974-$ & $1954, Q^{4}-$ & 1954, H1 - & 1969, Q4 - \\
\hline & & 2002, Q1 & & 2002, Q1 \\
\hline Periodicity & Monthly & Quarterly & Semi-Annual & Quarterly \\
\hline $\mathbf{N}$ & 290 & 169 & 96 & 125 \\
\hline
\end{tabular}

Notes: ${ }^{* * * * * *}{ }^{* *}$ and ${ }^{*}$ denote statistical significance at the $1 \%, 5 \%$ and $10 \%$ levels, respectively

(Newey-West standard errors in parentheses; correcting for autocorrelation up to one year)

Ball and Croushore (1995) interpret the estimated coefficients in a regression similar to that in Panel D as capturing the extent to which agents under or over react to 
information. For instance, under the implicit assumption that in the data high inflation this period will tend to be followed by high inflation in the next period, the finding that the coefficient on inflation in panel D is positive implies that agents have under-reacted to the recent inflation news. Our data supports this conclusion in three of the four regressions, with the Michigan series the exception. Similarly, a high nominal interest rate today could signal lower inflation tomorrow, since it indicates contractionary monetary policy by the Central Bank. We find that forecasts appear to under-react to short-term interest rates in all four regressions-high interest rates lead forecasters to make negative forecast errors, or predict future inflation that is too high. Finally, if in the economy a period of higher unemployment is usually followed by lower inflation (as found in estimates of the Phillips curve) then a negative coefficient on unemployment in panel D would indicate that agents are over-estimating inflation following a rise in unemployment, and thus are under-reacting to the news in higher unemployment. We find that inflation expectations of economists are indeed too high during periods of high unemployment, again suggesting a pattern of under-reaction; this is an error not shared by consumers. Our results are in line with Ball and Croushore's (1995) finding that agents seem to under-react to information when forming their expectations of inflation.

In sum, Table 4 suggests that each of these data series alternatively meets and fails some of the implications of rationality. Our sense is that these results probably capture the general flavor of the existing empirical literature, if not the somewhat stronger arguments made by individual authors. Bias exists, but is typically small. Forecasts are typically inefficient though not in all surveys: while the forecast errors of economists are not predictable based merely on their forecasts, those of consumers are. 
All four data series show substantial evidence that forecast errors made a year ago continue to repeat themselves, and that recent macroeconomic data is not adequately reflected in inflation expectations.

We now turn to analyzing whether the data are consistent with adaptive expectations, probably the most popular alternative to rational expectations in the literature. The simplest backward-looking rule invokes the prediction that expected inflation over the next year will be equal to inflation over the past year. Ball (2000) suggests a stronger version, whereby agents form statistically optimal univariate inflation forecasts. The test in Table 5 is a little less structured, simply regressing median inflation expectations against the last eight non-overlapping three-month-ended inflation observations. We add the unemployment rate and short-term interest rates to this regression, finding that these macroeconomic aggregates also help predict inflation expectations. In particular, it is clear that when the unemployment rate rises over the quarter, inflation expectations fall further than adaptive expectations might suggest. This suggests that consumers employ a more sophisticated model of the economy than assumed in the simple adaptive expectations model. 
Table 5: Tests of Adaptive Expectations: Median Inflation Expectations

$\begin{array}{cccc}\text { Michigan } & \begin{array}{c}\text { Michigan- } \\ \text { Experimental }\end{array} & \text { Livingston } & \text { SPF } \\ & & \text { (GDP } \\ & & \text { deflator) }\end{array}$

\begin{tabular}{|c|c|c|c|c|}
\hline \multicolumn{5}{|c|}{ Adaptive expectations: $\mathbf{E}_{t} \pi_{t+12}=\alpha+\beta(L) \pi_{t}+\gamma \mathbf{U}_{t}+\kappa \mathbf{U}_{t-3}+\delta i_{t}+\phi i_{t-3}$} \\
\hline Inflation & $0.706^{* * *}$ & $0.635^{* * *}$ & $0.530^{* * *}$ & $0.581^{* * *}$ \\
\hline$\beta(1)$ : Sum of 8 coeffs & $(0.037)$ & $(0.085)$ & $(0.048)$ & $(0.054)$ \\
\hline \multicolumn{5}{|l|}{ Unemployment } \\
\hline \multirow[t]{2}{*}{$\gamma:$ Date of Forecast } & $-0.633^{* *}$ & $-1.237^{* *}$ & $-0.755^{* * *}$ & $-0.405^{* *}$ \\
\hline & $(0.261)$ & $(0.488)$ & $(0.192)$ & $(0.162)$ \\
\hline \multirow[t]{2}{*}{ к: 3 months prior } & 0.585 & 0.555 & $1.055^{* * *}$ & $0.593^{* * *}$ \\
\hline & $(0.231)$ & $(0.467)$ & $(0.185)$ & $(0.171)$ \\
\hline \multicolumn{5}{|l|}{ Treasury Bill Rate } \\
\hline \multirow[t]{2}{*}{$\delta$ : Date of forecast } & 0.035 & -0.053 & $0.143^{* *}$ & $0.069^{*}$ \\
\hline & $(0.038)$ & $(0.132)$ & $(0.058)$ & $(0.039)$ \\
\hline \multirow[t]{2}{*}{$\phi: 3$ months prior } & $-0.109^{* *}$ & -0.052 & $0.100^{* *}$ & $0.144^{* * *}$ \\
\hline & $(0.045)$ & $(0.122)$ & $(0.049)$ & $(0.047)$ \\
\hline \multirow{3}{*}{$\begin{array}{l}\text { Reject adaptive } \\
\text { expectations? } \\
(\gamma=\kappa=\delta=\phi=0)\end{array}$} & $\mathrm{F}_{4,277}=9.94^{* * *}$ & $\mathrm{~F}_{4,156}=6.67^{* * *}$ & $\mathrm{~F}_{4,83}=24.5^{* * *}$ & $\mathrm{~F}_{4,112}=13.4^{* * *}$ \\
\hline & Yes & Yes & Yes & Yes \\
\hline & & & & \\
\hline \multirow{3}{*}{$\begin{array}{l}\text { Adj. } \mathbf{R}^{2} \\
\mathrm{~N}\end{array}$} & 0.922 & 0.539 & 0.916 & 0.929 \\
\hline & 290 & 169 & 96 & 125 \\
\hline & (Monthly) & (Quarterly) & (Semi-annual) & (Quarterly) \\
\hline
\end{tabular}

Notes: ${ }^{* * * * *}{ }^{* *}$ and ${ }^{*}$ denote statistical significance at the $1 \%, 5 \%$ and $10 \%$ levels, respectively

(Newey-West standard errors in parentheses; correcting for autocorrelation up to a year)

Consequently we are left with a somewhat negative result - observed inflation expectations are consistent with neither the sophistication of rational expectations, nor the naiveté of adaptive expectations. This finding holds for our four datasets, and it offers a reasonable interpretation of the prior literature on inflation expectations. The common thread to these results is that inflation expectations reflect partial, but incomplete updating in response to macroeconomic news. We shall argue in section $\mathrm{V}$ that these results are consistent with models in which expectations are not updated at every instant, but rather in which updating occurs in a staggered fashion. A key implication is that disagreement will vary with macroeconomic conditions. 


\section{DiSPERSION IN SURVEY MEASURES OF INFLATION EXPECTATIONS}

Few papers have explored the features of the cross-sectional variation in inflation expectations.

Bryan and Venkatu (2001) examine a survey of inflation expectations in Ohio from 1998-2001, finding that women, singles, non-whites, high school dropouts and lower income groups tend to have higher inflation expectations than other demographic groups. They note that these differences are too large to be explained by differences in the consumption basket across groups, but present suggestive evidence that differences in expected inflation reflect differences in perceptions of current inflation rates. VissingJorgenson (this volume) also explores differences in inflation expectations across age groups.

Souleles (2001) finds complementary evidence from the Michigan survey that expectations vary by demographic group, a fact that he interprets as evidence of nonrational expectations. Divergent expectations across groups lead to different expectation errors, which he relates to differential changes in consumption across groups.

A somewhat larger literature has employed data on the dispersion in inflation expectations as a rough proxy for "inflation uncertainty." These papers have suggested that highly dispersed inflation expectations are positively correlated with the inflation rate, and conditional on current inflation, are related positively to the recent variance of measured inflation (Cukierman and Wachtel 1979), to weakness in the real economy

(Mullineaux, 1980, Makin 1982), and alternatively to lower interest rates (Levi and Makin, 1979, Bomberger and Frazer, 1981, and Makin 1983) and to higher interest rates (Barnea, Dotan and Lakonishok, 1979, Brenner and Landskroner, 1983.) These 
relationships do not appear to be particularly robust, and in no case is more than one set of expectations data brought to bear on the question.

Our approach is consistent with a more literal interpretation of the second moment of the expectations data: we interpret different inflation expectations as reflecting disagreement in the population. That is, different forecasts reflect different expectations.

Llambros and Zarnowitz (1987) argue that disagreement and uncertainty are conceptually distinct, and they make an attempt at unlocking the two empirically. Their data on uncertainty derives from the SPF, which asks respondents to supplement their point estimates with estimates of the probability that GDP and the implicit price deflator will fall into various ranges. These two authors find only weak evidence that uncertainty and disagreement share a common time series pattern. Intrapersonal variation in expected inflation ("uncertainty") is larger than interpersonal variation ("disagreement"), and while there are pronounced changes through time in disagreement, uncertainty varies very little.

The most closely related approach to the macroeconomics of disagreement comes from Carroll (2003b), who analyzes the evolution of the standard deviation of inflation expectations in the Michigan Survey. Carroll provides an epidemiological model of inflation expectations in which "expert opinion" slowly spreads person-to-person much as disease spreads through a population. His formal model yields something very close to the Mankiw and Reis (2002) formulation of the sticky-information model. In an agentbased simulation, he proxies expert opinion by the average forecast in the Survey of Professional Forecasters, and finds that his agent-based model tracks the time series of disagreement quite well, although it cannot match the level of disagreement in the population. 
We now turn to analyzing the evolution of disagreement in greater detail. Figure 3 showed the inflation rate and our measures of disagreement. That figure suggested a relatively strong relationship between inflation and disagreement. A clearer sense of this relationship can be seen in Figure 5.

Figure 5. Inflation and Disagreement

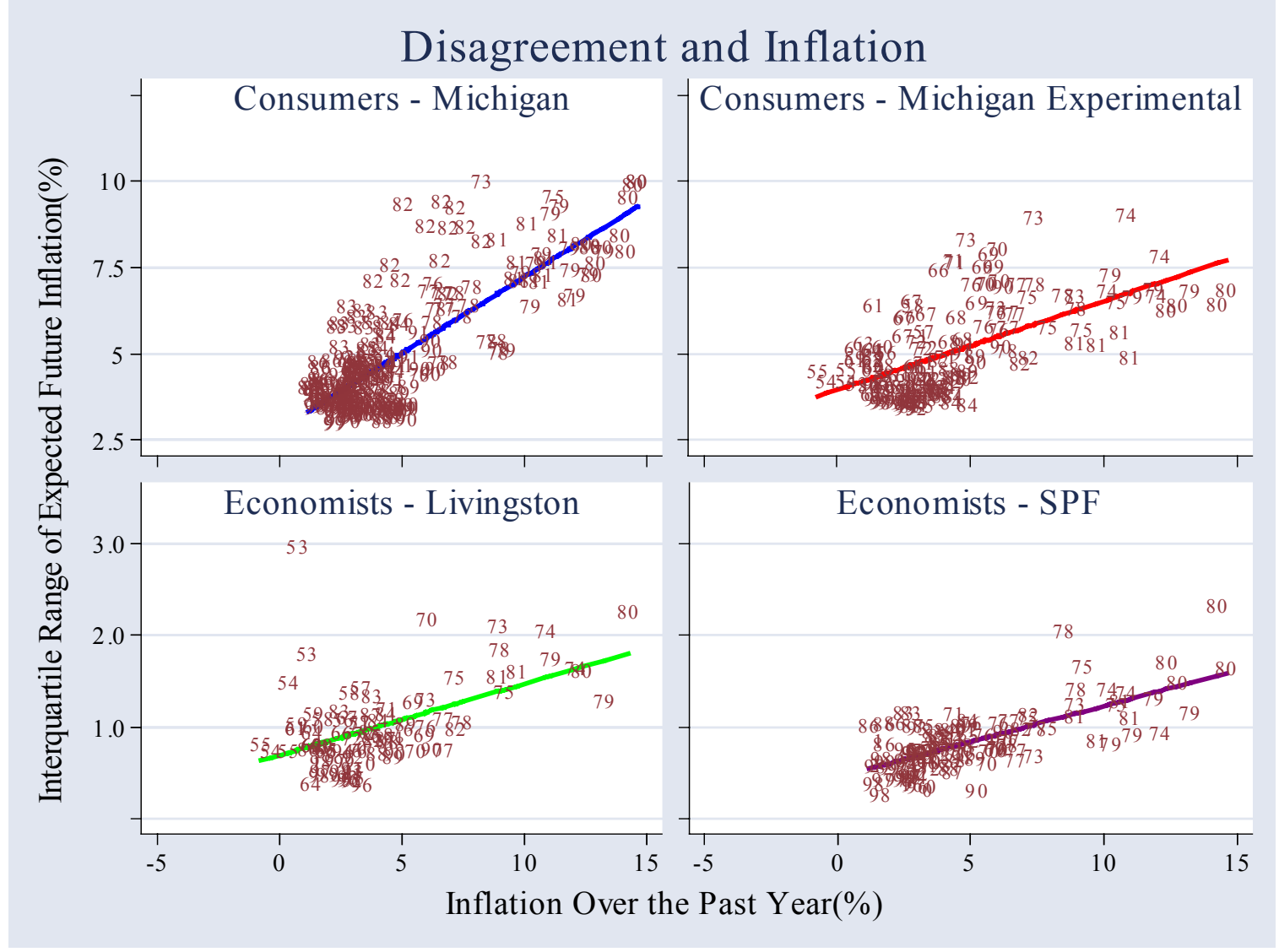

Beyond this simple relationship in levels, an equally apparent fact from Figure 3 is that when the inflation rate moves around a lot, dispersion appears to rise. This fact is illustrated in Figure 6. 
Figure 6. Changes in Inflation and Disagreement

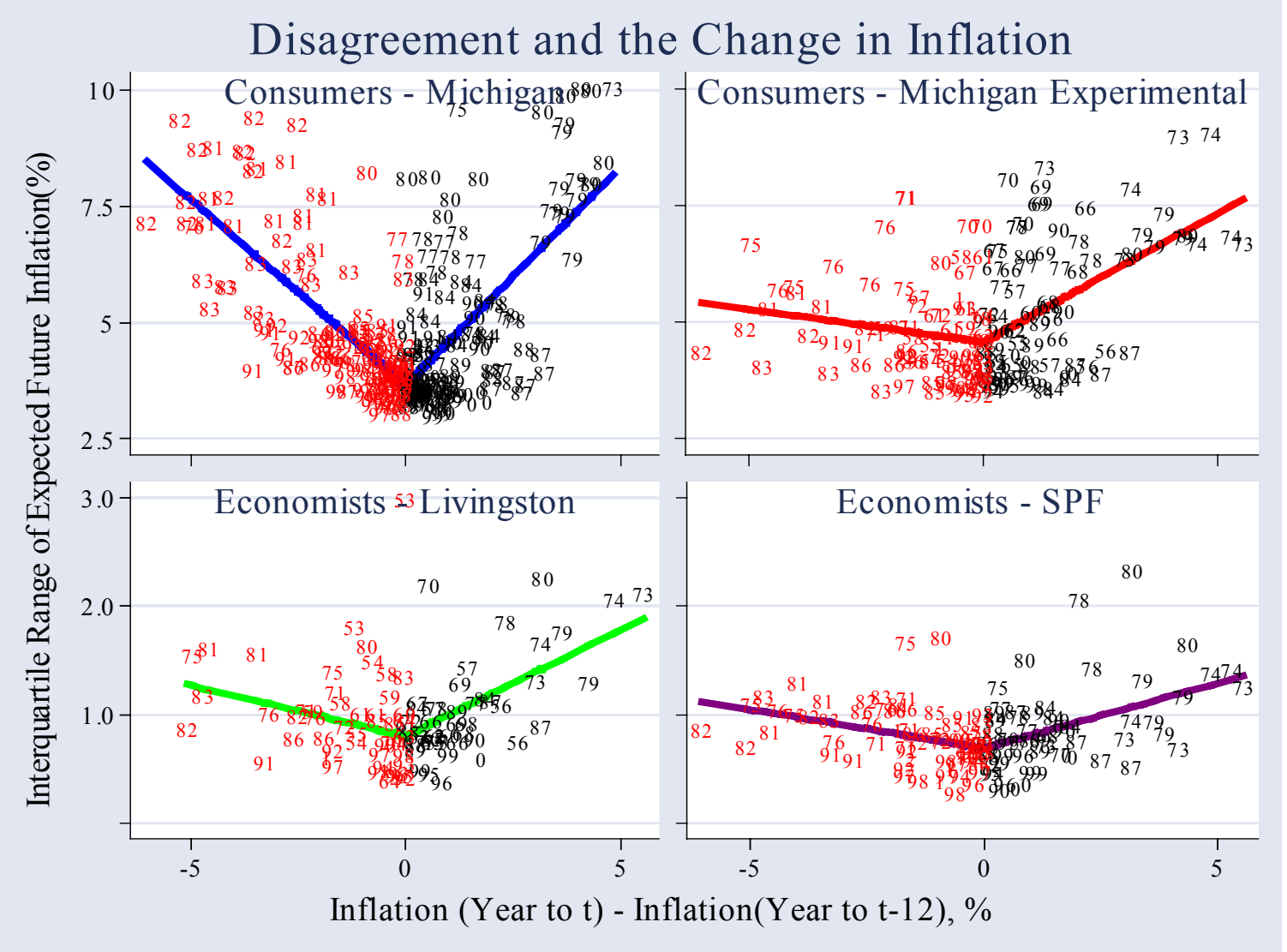

In all four datasets, large changes in inflation (in either direction) are correlated with an increase in disagreement. This fanning out of inflation expectations following a change in inflation is consistent with a process of staggered adjustment of expectations. Of course, the change in inflation is (mechanically) related to its level, and we will provide a more careful attempt at sorting out change and level effects below.

Figure 7 maps the evolution of disagreement and the real economy through time. The chart shows our standard measures of disagreement, plus two measures of excess capacity: an output gap constructed as the difference between the natural logs of actual chain-weighted real output and trend output (constructed from a Hodrick-Prescott filter), 
and shaded regions representing periods of economic expansion and contraction as marked by the NBER Business Cycle Dating Committee. ${ }^{8}$

Figure 7: Disagreement and the Real Economy

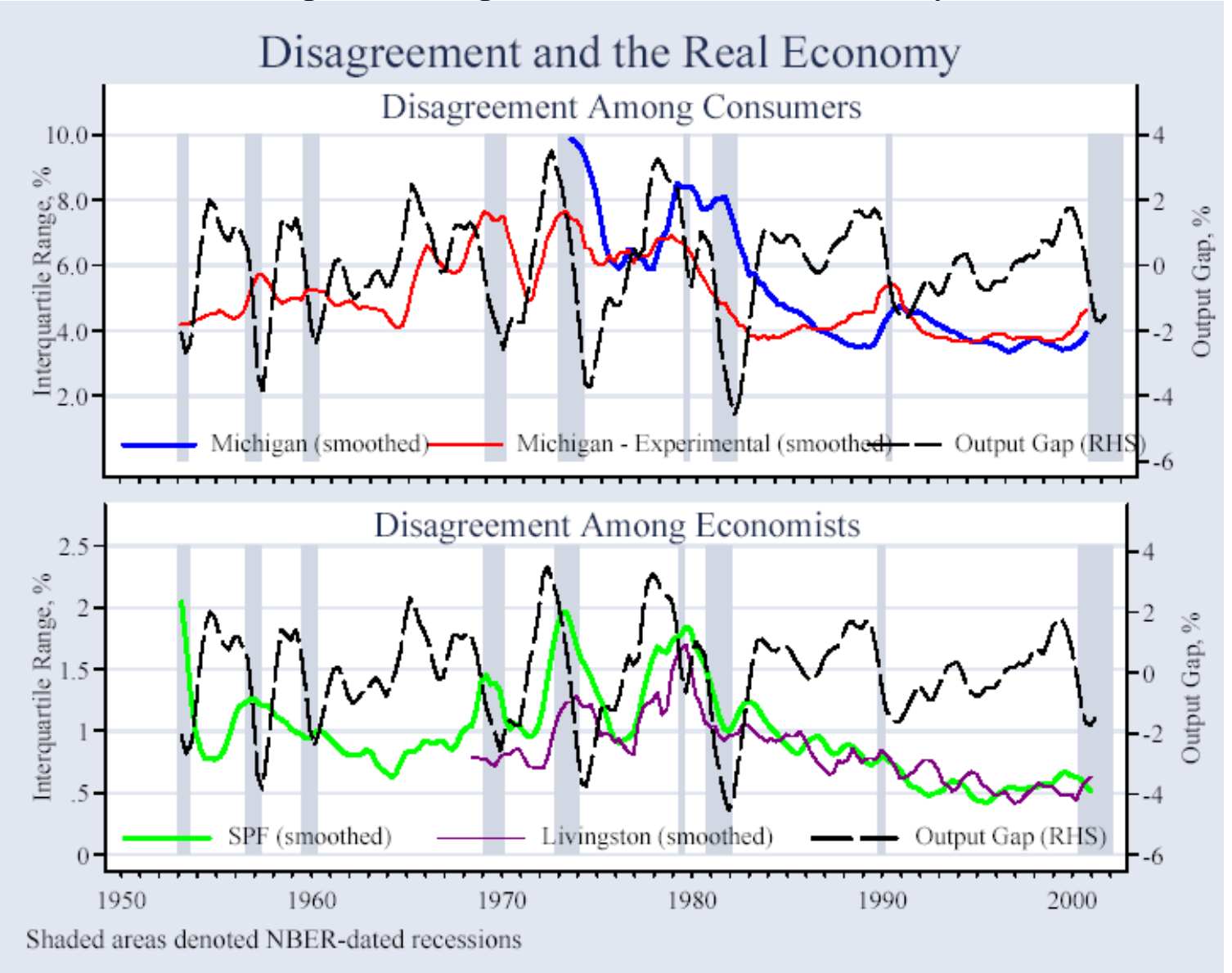

The series on disagreement among consumers appears to rise during recessions, at least through the second half of the sample. A much weaker relationship is observed through the first half of the sample. Disagreement among economists shows a less obvious relationship with the state of the real economy.

The final set of data that we examine can be thought of as either a cause or consequence of disagreement in inflation expectations. We consider the dispersion in

\footnotetext{
${ }^{8}$ We have also experimented using the unemployment rate as a measure of real activity, and obtained similar results.
} 
actual price changes across different CPI categories. That is, just as Bryan and Cecchetti (1994) produce a weighted median CPI by calculating rates of inflation across 36 commodity groups, we construct a weighted interquartile range of year-ended inflation rates across commodity groups. One could consider this a measure of the extent to which relative prices are changing. We analyze data for the period December 1967-December 1997 provided by the Cleveland Fed. Figure 8 shows the median inflation rate, as well as the 25 th and 75 th percentiles of the distribution of nominal price changes.

Figure 8: Distribution of Price Changes Across CPI Components

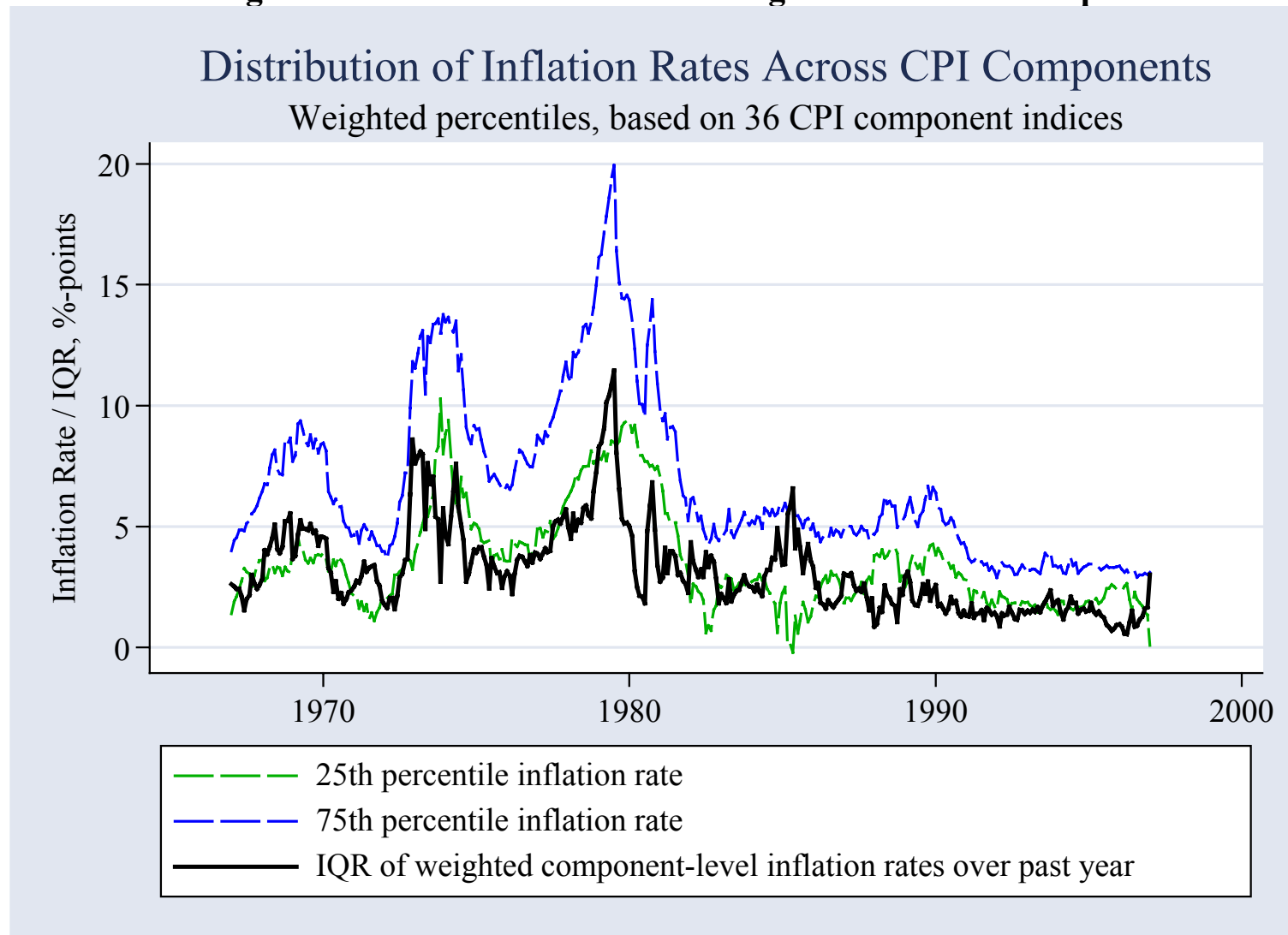

Dispersion in commodity-level rates of inflation seems to rise during periods in which the dispersion in inflation expectations rise. In Figure 9, we confirm this, graphing this measure of dispersion in rates of price change against our measures of dispersion in expectations. Interestingly, the two look to be quite closely related. 
Figure 9: Dispersion in Inflation Expectations and Dispersion in Inflation Rates across different CPI Components.

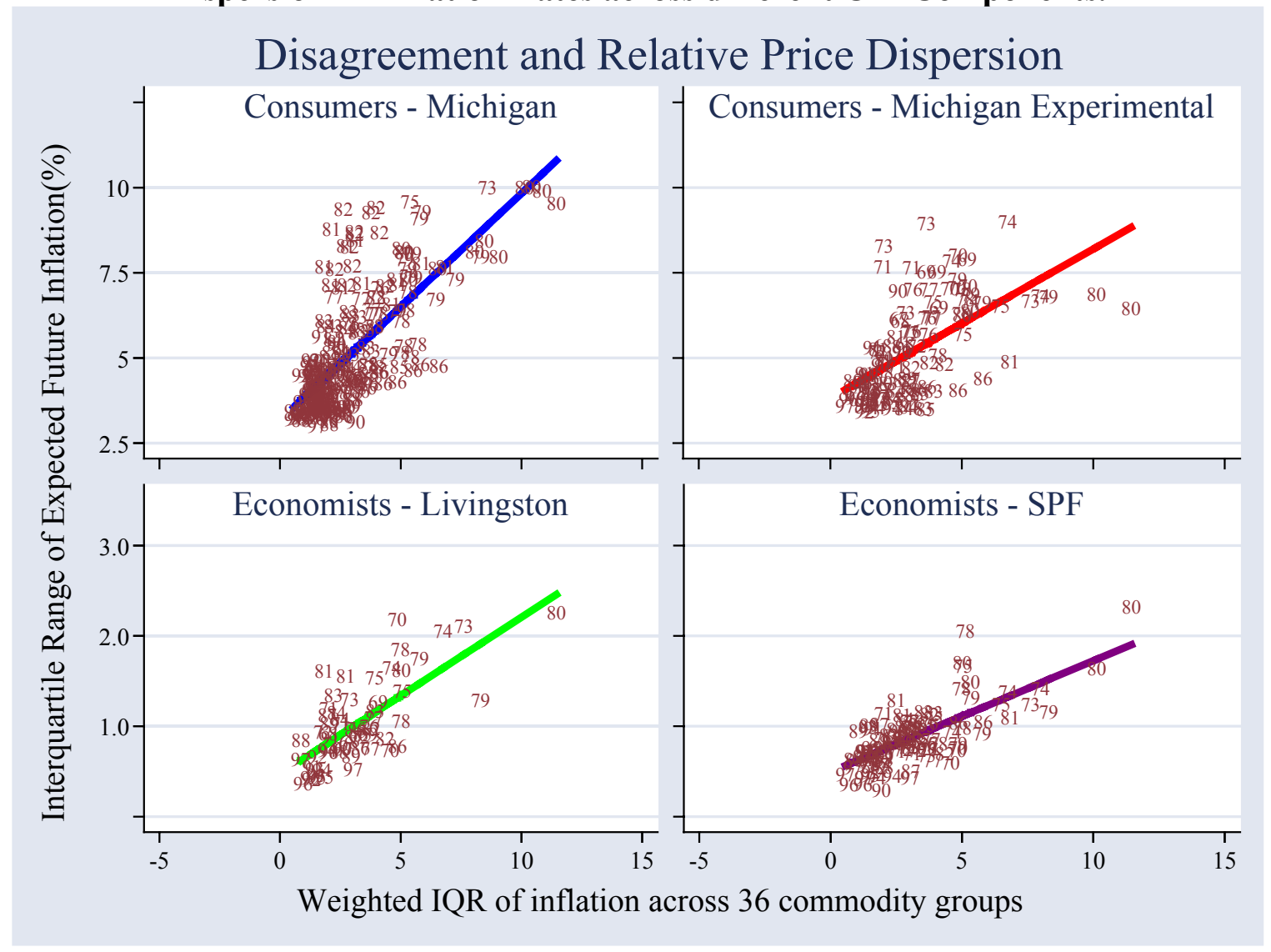

Table 6 considers each of the factors discussed above simultaneously, reporting regressions of the level of disagreement against inflation, the squared change in inflation, the output gap, and dispersion in different commodities' actual inflation rates. 
Table 6: Disagreement and the Business Cycle - Establishing Stylized Facts

$\begin{array}{llll}\text { Michigan } & \text { Michigan - } & \text { Livingston } & \text { SPF } \\ & \text { Experimental } & & \text { (GDP } \\ & & \text { deflator) }\end{array}$

\begin{tabular}{lllll}
\hline $\begin{array}{l}\text { Panel A: Bivariate Regressions } \\
\text { (Each Cell Represents a Separate Regression) }\end{array}$ & & \\
\hline \multicolumn{1}{l}{ Inflation Rate } & $0.441^{* * *}$ & $0.228^{* * *}$ & $0.083^{* * *}$ & $0.092^{* * *}$ \\
& $(0.028)$ & $(0.036)$ & $(0.016)$ & $(0.013)$ \\
DInflation-squared & $18.227^{* * *}$ & $1.259^{* * *}$ & $2.682^{* * *}$ & $2.292^{* *}$ \\
& $(2.920)$ & $(0.616)$ & $(0.429)$ & $(0.084)$ \\
Output Gap & 0.176 & -0.047 & $0.070^{* *}$ & -0.001 \\
& $(0.237)$ & $(0.092)$ & $(0.035)$ & $(0.029)$ \\
Relative Price & $0.665^{* * *}$ & $0.473^{* * *}$ & $0.117^{* *}$ & 0.132 \\
Variability & $(0.056)$ & $(0.091)$ & $(0.046)$ & $(0.016)$ \\
\hline
\end{tabular}

Panel B: Regressions controlling for the Inflation Rate (Each Cell Represents a Separate Regression)

\begin{tabular}{|c|c|c|c|c|}
\hline$\Delta$ Inflation-squared & $10.401^{* * * *}$ & $\begin{array}{l}0.814 \\
(0607)\end{array}$ & $\begin{array}{l}2.051^{* * *} \\
(0483)\end{array}$ & $\begin{array}{l}-0.406 \\
(0.641)\end{array}$ \\
\hline \multirow[t]{2}{*}{ Output Gap } & $0.415^{* * *}$ & $\begin{array}{l}(0.00 /) \\
0.026\end{array}$ & $-0.062^{* *}$ & $\begin{array}{l}(0.041) \\
-0.009\end{array}$ \\
\hline & $(0.088)$ & $(0.086)$ & $(0.027)$ & $(0.013)$ \\
\hline Relative Price & $0.268^{* * *}$ & 0.210 & $0.085^{* *}$ & $0.099^{* * *}$ \\
\hline Variability & $(0.092)$ & $(0.135)$ & $(0.042)$ & $(0.020)$ \\
\hline \multicolumn{5}{|c|}{ Panel C: Multivariate Regressions (Full Sample) } \\
\hline Inflation Rate & $\begin{array}{l}0.408^{* * * *} \\
(0.028)\end{array}$ & $\begin{array}{l}0.217^{* * *} \\
(0.034)\end{array}$ & $\begin{array}{l}0.066^{* * *} \\
(0.013)\end{array}$ & $\begin{array}{l}0.095^{* * * *} \\
(0.015)\end{array}$ \\
\hline$\Delta$ Inflation-squared & $\begin{array}{l}7.062^{* * *} \\
(1.364)\end{array}$ & $\begin{array}{l}0.789 \\
(0.598)\end{array}$ & $\begin{array}{l}1.663^{* *} \\
(0.737)\end{array}$ & $\begin{array}{l}-0.305 \\
(0.676)\end{array}$ \\
\hline Output Gap & $\begin{array}{l}0.293^{* * * *} \\
(0.066)\end{array}$ & $\begin{array}{l}0.017 \\
(0.079)\end{array}$ & $\begin{array}{l}0.020 \\
(0.032)\end{array}$ & $\begin{array}{l}-0.007 \\
(0.014)\end{array}$ \\
\hline \multicolumn{5}{|c|}{ Panel D: Multivariate Regressions (Including inflation dispersion) } \\
\hline Inflation Rate & $\begin{array}{l}0.328^{* * *} \\
(0.034)\end{array}$ & $\begin{array}{l}0.204^{\text {*** }} \\
(0.074)\end{array}$ & $\begin{array}{l}0.044^{* *} \\
(0.018)\end{array}$ & $\begin{array}{l}0.037^{* * *} \\
(0.011)\end{array}$ \\
\hline$\Delta$ Inflation-squared & $\begin{array}{l}5.558^{* * * *} \\
(1.309)\end{array}$ & $\begin{array}{l}-0.320 \\
(2.431)\end{array}$ & $\begin{array}{l}1.398 \\
(0.949)\end{array}$ & $\begin{array}{l}-0.411 \\
(0.624)\end{array}$ \\
\hline Output Gap & $\begin{array}{l}0.336^{* * *} \\
(0.067)\end{array}$ & $\begin{array}{l}-0.061 \\
(0.117)\end{array}$ & $\begin{array}{l}0.013 \\
(0.039)\end{array}$ & $\begin{array}{l}0.006 \\
(0.018)\end{array}$ \\
\hline $\begin{array}{l}\text { Relative Price } \\
\text { Variability }\end{array}$ & $\begin{array}{l}0.237^{* * * *} \\
(0.079)\end{array}$ & $\begin{array}{l}0.210 \\
(0.159)\end{array}$ & $\begin{array}{l}0.062 \\
(0.038)\end{array}$ & $\begin{array}{l}0.100^{* * * *} \\
(0.022)\end{array}$ \\
\hline
\end{tabular}

Notes: ${ }^{* * * *},{ }^{* *}$ and ${ }^{*}$ denote statistical significance at the $1 \%, 5 \%$ and $10 \%$ levels, respectively

(Newey-West standard errors in parentheses; correcting for autocorrelation up to one year)

Across the four columns, we tend to find larger coefficients in the regressions focusing on consumer expectations than in those of economists. This reflects the 
differences in the extent of disagreement, and how much it varies over the cycle, across these populations.

In both bivariate and multivariate regressions, we find the inflation rate to be an extremely robust predictor of disagreement. The squared change in inflation is highly correlated with disagreement in bivariate regressions, and controlling for the inflation rate and other macroeconomic variables only slightly weakens this effect. Adding the relative price variability term further weakens this effect. Relative price variability is a consistently strong predictor of disagreement across all specifications. These results are generally stronger for the actual Michigan data than for the experimental series, and for the Livingston series than for the SPF; we suspect that both of these facts reflect the relative role of measurement error. Finally, while the output gap appears to be related to disagreement in certain series, this finding is not robust either across data series, or to the inclusion of controls.

In sum, our analysis of the disagreement data has estimated that disagreement about the future path of inflation tends to:

- Rise with inflation.

- Rise when inflation changes sharply - in either direction.

- Rise in concert with dispersion in rates of inflation across commodity groups.

- Show no clear relationship with measures of real activity.

Finally, we end this section with a note of caution. None of these findings necessarily reflect causality, and in any case, we have deliberately been quite loose in even speaking about the direction of likely causation. However, we believe that these 
findings present a useful set of stylized facts that a theory of macroeconomic dynamics should aim to explain.

\section{THEORIES OF DISAGREEMENT}

Most theories in macroeconomics have no disagreement among agents. It is assumed that everyone shares the same information and that all are endowed with the same information processing technology. Consequently, everyone ends up with the same expectations.

A famous exception is the islands model of Robert Lucas (1973). Producers are assumed to live in separate islands and to specialize in producing a single good. The relative price for each good differs by island-specific shocks. At a given point in time, producers can only observe the price in their given island and from it they must infer how much of it is idiosyncratic to their product, and how much reflects the general price level that is common to all islands. Since agents have different information, they have different forecasts of prices and hence inflation. Since all will inevitably make forecast errors, unanticipated monetary policy affects real output: Following a change in the money supply, producers attribute some of the observed change in the price for their product to changes in relative rather than general prices and react by expanding production.

This model relies on disagreement among agents and predicts dispersion in inflation expectations as we observe in the data. Nonetheless, the extent of this disagreement is given exogenously by the parameters of the model. Although the Lucas model has heterogeneity in inflation expectations, the extent of disagreement is constant and unrelated to any macroeconomic variables. It cannot account for the systematic 
relation between dispersion of expectations and macroeconomic conditions that we documented in section IV.

The sticky-information model of Mankiw and Reis (2002) generates disagreement in expectations that is endogenous to the model and correlated with aggregate variables. In this model, costs of acquiring and processing information and of re-optimizing lead agents to update their information sets and expectations sporadically. Each period, only a fraction of the population update themselves on the current state of the economy and determine their optimal actions, taking account of the likely delay until they will revisit their plans. The rest of the population continues to act according to their pre-existing plans based on old information. This theory generates heterogeneity in expectations because different segments of the population will have updated their expectations at different points in time. The evolution of the state of the economy over time will endogenously determine the extent of this disagreement. This disagreement in turn affects agents' actions and the resulting equilibrium evolution of the economy.

We conducted the following experiment to assess whether the sticky-information model can capture the extent of disagreement in the survey data. To generate rational forecasts from the perspective of different points in time, we estimated a vector autoregression on U.S. monthly data. The VAR included three variables: monthly inflation (measured by the CPI), the interest rate on 3-month Treasury bills, and a measure of the output gap, obtained by using the Hodrick-Prescott filter on interpolated quarterly real GDP. ${ }^{9}$ The estimation period was from March of 1947 to March of 2002,

\footnotetext{
${ }^{9}$ Using employment rather than de-trended GDP as the measure of real activity leads to essentially the same results.
} 
and the regressions included 12 lags of each variable. We take this estimated VAR as an approximation to the model rational agents use to form their forecasts.

We follow Mankiw and Reis (2002) and assume that each period a fraction $\lambda$ of the population obtain new information about the state of the economy and recomputes optimal expectations based on this new information. Each person has the same probability of updating their information, regardless of how long it has been since the last update. The VAR is then used to produce estimates of future annual inflation in the United States given information at different points in the past. To each of these forecasts we attribute a frequency as dictated by the process just described. This generates at each point in time a full cross-sectional distribution of annual inflation expectations. We use the predictions from 1954 onwards, discarding the first few years in the sample, when there are not enough past observations to produce non-degenerate distributions.

We compare the predicted distribution of inflation expectations by the stickyinformation model to the distribution we observe in the survey data. To do so meaningfully we need a relatively long sample period. This leads us to focus on the Livingston and the Michigan experimental series, which are available for the entire postwar period.

The parameter which governs the rate of information updating in the economy, $\lambda$, is chosen to maximize the correlation between the interquartile range of inflation expectations in the survey data with that predicted by the model. For the Livingston survey, the optimal $\lambda$ is 0.10 , implying that the professional economists surveyed are updating their expectations about every 10 months, on average. For the Michigan series, the value of $\lambda$ that maximizes the correlation between predicted and actual dispersion is 
0.08, implying that the general public updates their expectations on average every 12.5 months. These estimates are in line with those obtained by Mankiw and Reis (2003), Carroll (2003a) and Khan and Zhu (2002). These authors employ different identification schemes, and estimate that agents update their information sets on average once a year. Our estimates are also consistent with the reasonable expectation that people in the general public update their information less frequently than professional economists. It is more surprising that the difference between the two is so small.

A first test of the model is to see to what extent it can predict the dispersion in expectations over time. Figure 10 plots the evolution of the interquartile range predicted by the sticky-information model, given the history of macroeconomic shocks and VARtype updating and setting $\lambda=0.1$. The predicted interquartile range matches the key features of the Livingston data closely, and the two series appear to move closely together. The correlation between them is 0.66 . The model is also successful at matching the absolute level of disagreement. While it over-predicts dispersion, it does so only by 0.18 percentage points on average. 
Figure 10. Actual and Predicted Dispersion of Inflation Expectations:

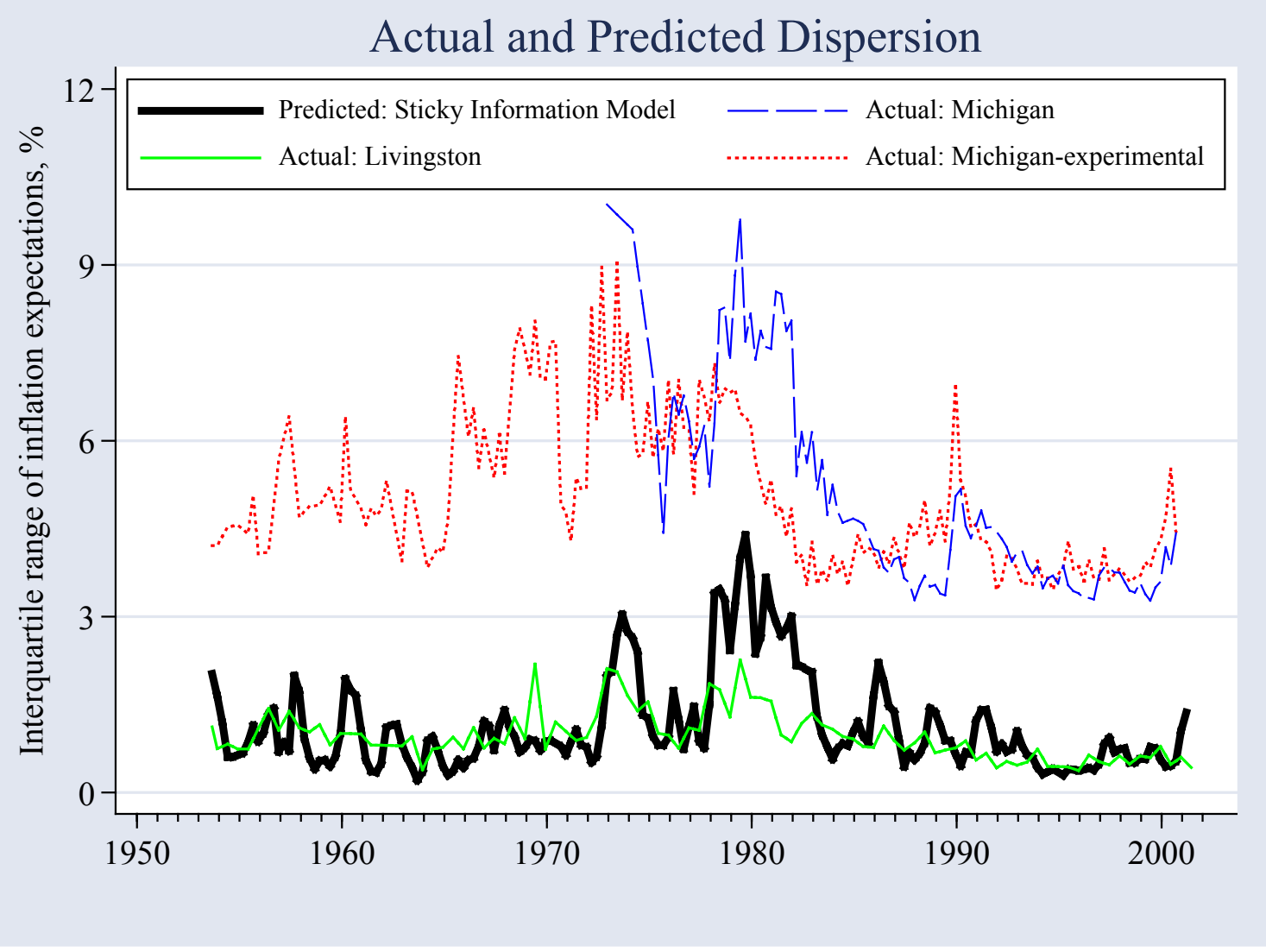

The sticky-information model also predicts the time series movement in disagreement among consumers nicely. The correlation between the predicted and actual series is 0.80 for the actual Michigan data and 0.40 for the longer experimental series. As for the level of dispersion, it is on average 4 percentage points higher in the data than predicted by the model. This may be partially accounted for by some measurement error in the construction of the Michigan series. More likely though, it reflects idiosyncratic heterogeneity in the population that is not captured by the model. Individuals in the public probably differ in their sources of information, in their sophistication in making forecasts, or even in their commitment to truthful reporting in a survey. None of these 
sources of individual-level variation are captured by the sticky-information model, but they might cause the high levels of disagreement observed in the data. ${ }^{10}$

Section IV outlined a number of stylized facts regarding the dispersion of inflation expectations in the survey data. The interquartile range of expected inflation was found to rise with inflation and with the squared change in annual inflation over the last year. The output gap did not seem to significantly affect the dispersion of inflation expectations. We re-estimate the regressions in panels $\mathrm{A}$ and $\mathrm{C}$ of Table 6 , now using as the dependant variable the dispersion in inflation expectations predicted by the stickyinformation model with a $\lambda$ of 0.1 , the value we estimated using the Livingston series. ${ }^{11}$ Table 7 presents the results. Comparing Table 7 with Table 6, we see that the dispersion of inflation expectations predicted by the sticky-information model has essentially the same properties as the actual dispersion of expectations we find in the survey data. As is true in survey data, the dispersion in sticky-information expectations is also higher when inflation is high, and higher when prices have changed sharply. As with the survey data, the output gap does not have a statistically significant effect on the model-generated dispersion of inflation expectations. ${ }^{12}$

\footnotetext{
${ }^{10}$ An interesting illustration of this heterogeneity is provided by Bryan and Ventaku (2001) who find that men and women in the Michigan survey have statistically significant different expectations of inflation. Needless to say, the sticky information model does not incorporate gender heterogeneity.

${ }^{11}$ Using instead the value of $\lambda$ that gave the best fit with the Michigan series $(0.08)$ gives similar results.

12 The sticky-information model can also replicate the stylized fact from section $\mathrm{V}$ that more disagreement comes with larger relative price dispersion. Indeed, in the sticky-information model, different price setters only choose different prices insofar as they disagree on their expectations. This is transparent in Ball, Mankiw and Reis (2003), where it is shown that relative price variability in the sticky-information model is a weighted sum of the squared deviations of the price level from the levels expected at all past dates, with earlier expectations receiving smaller weights. In the context of the experiment in this section, including relative price dispersion as an explanatory variable for the disagreement of inflation expectations would risk confounding consequences of disagreement with its driving forces.
} 


\begin{tabular}{lcc}
\hline & $\begin{array}{c}\text { Multivariate } \\
\text { regression }\end{array}$ & $\begin{array}{c}\text { Bivariate } \\
\text { regressions }\end{array}$ \\
\hline Dependent Variable: Interquartile range of model-generated inflation expectations \\
\hline Constant & $0.005^{* * *}$ & \\
Inflation Rate & $(0.001)$ & $0.166^{* * *}$ \\
SInflation-squared & $0.127^{* * *}$ & $(0.027)$ \\
& $(0.028)$ & $6.702^{* * * *}$ \\
Output Gap & $3.581^{* * * *}$ & $(1.389)$ \\
& $(0.928)$ & 0.018 \\
Adj. $\mathbf{R}^{2}$ & 0.009 & $(0.080)$ \\
N & $(0.051)$ & 579 \\
\hline Notes: ${ }^{* * *}{ }^{* *}{ }^{2}$ and ${ }^{*}$ denote statistical significance at the $1 \%, 5 \%$ and $10 \%$ levels, respectively \\
(Newey-West standard errors in parentheses; correcting for autocorrelation up to one year)
\end{tabular}

We can also see whether the model is successful at predicting the central tendency of expectations, not just dispersion. Figure 11 plots the median expected inflation, both in the Livingston and Michigan surveys and as predicted by the sticky-information model with $\lambda=0.1$. The Livingston and predicted series move closely with each other: the correlation is 0.87 . The model slightly over-predicts the data between 1955 and 1965 and it under-predicts median expected inflation between 1975 and 1980. On average these two cancel out, so that over the whole sample, the model approximately matches the level of expected inflation (it over-predicts it by $0.3 \%$ ). The correlation coefficient between the predicted and the Michigan experimental series is 0.49 , and on average the model matches the level of median inflation expectations, under-predicting it by only $0.5 \%$. 
Figure 11: Actual and Predicted Median Inflation Expectations

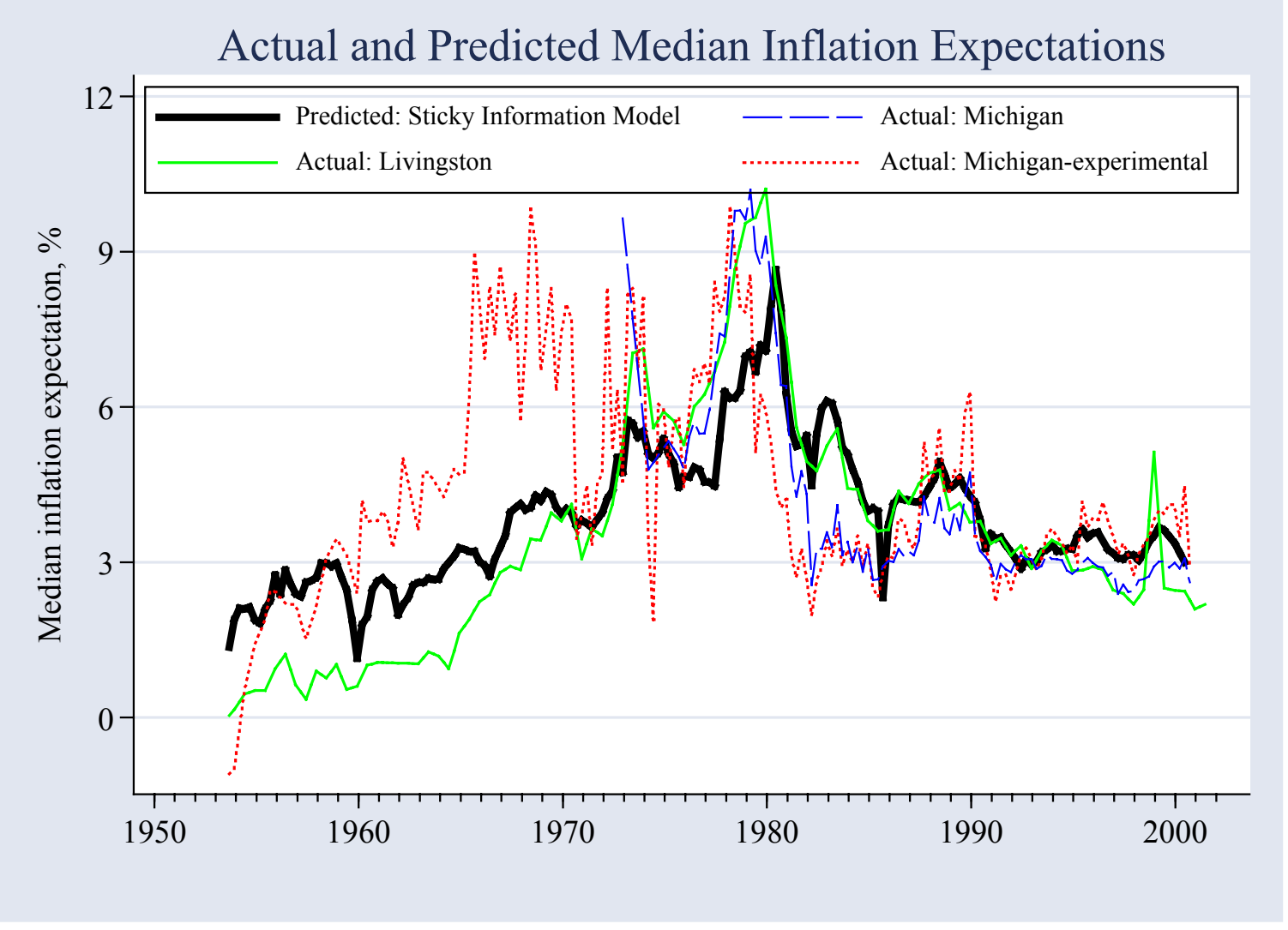

In section III, we studied the properties of the median inflation expectations across the different surveys, finding that these data were consistent with weaker, but not stronger tests of rationality. Table 8 is the counterpart to Table 4 , using as the dependent variable the median expected inflation series generated by the sticky-information model. Again, these results closely match the data. We cannot reject the hypothesis that expectations are unbiased and efficient in the weak sense of panels A and B. Recall that in the data, we found mixed evidence regarding these tests. Panels C and D suggest that forecasting errors in the sticky-information expectations are persistent and do not fully incorporate macroeconomic data, just as we found was consistently true in the survey data. 
Table 8: Tests of Forecast Rationality:

Median Inflation Expectations Predicted by the Sticky-information Model

Panel A: Testing for Bias: $\pi_{t}-E_{t-12} \pi_{t}=\alpha$

Mean Error

$0.262 \%$

(Constant only)

$(0.310)$

\begin{tabular}{lc} 
Panel B: Is Information in the Forecast Fully Exploited? $\boldsymbol{\pi}_{\mathbf{t}}-\mathbf{E}_{\mathbf{t}-12} \boldsymbol{\pi}_{\mathbf{t}}=\boldsymbol{\alpha}+\boldsymbol{\beta} \mathbf{E}_{\mathbf{t}-12} \boldsymbol{\pi}_{\mathbf{t}}$ \\
\hline $\boldsymbol{\beta}: \mathbf{E}_{\mathbf{t}-12}\left[\boldsymbol{\pi}_{\mathbf{t}}\right]$ & $0.436^{*}$ \\
& $(0.261)$ \\
$\boldsymbol{\alpha}:$ Constant & $-1.416 \%{ }^{*}$ \\
& $(0.822)$ \\
Adj. $\mathbf{R}^{2}$ & 0.088 \\
Reject Efficiency? & No \\
$\boldsymbol{\alpha}=\boldsymbol{\beta}=\mathbf{0}$ & $\mathrm{p}=0.227$ \\
\hline
\end{tabular}

$\alpha=\beta=0$
Panel C: Are Forecasting Errors Persistent? $\pi_{t}-E_{t-12} \pi_{t}=\alpha+\beta\left(\pi_{t-12}-E_{t-24} \pi_{t-12}\right)$

$\pi_{\mathrm{t}-12}-\mathbf{E t}_{-24}\left[\boldsymbol{\pi}_{\mathrm{t}-12}\right] \quad 0.604^{* *}$

Constant

$0.107 \%$

Adj. $\mathbf{R}^{2}$

$(0.211)$

0.361

Panel D: Are Macroeconomic data fully exploited?

$\pi_{\mathrm{t}}-\mathbf{E}_{\mathrm{t}-12} \pi_{\mathrm{t}}=\alpha+\beta \mathbf{E}_{\mathrm{t}-12}\left[\boldsymbol{\pi}_{\mathrm{t}}\right]+\gamma \pi_{\mathrm{t}-13}+\kappa \mathbf{i}_{\mathrm{t}-13}+\delta \mathbf{U}_{\mathrm{t}-13}$

$\alpha:$ Constant

$\beta: \mathbf{E}_{\mathrm{t}-12}\left[\boldsymbol{\pi}_{\mathrm{t}}\right]$

$\gamma:$ Inflation $_{\mathrm{t}-13}$

к: Treasury Bill t-13

$\delta$ : Unemployment t-13

Reject Efficiency?

$\gamma=\kappa=\delta=0$

Adj. $\mathbf{R}^{2}$

Notes:

(Newey-West standard errors in parentheses; correcting for autocorrelation up to one year)
$1.567 \% \%^{*}$

$(0.824)$

0.398

$(0.329)$

$0.506^{* * *}$

(0.117)

$-0.413^{* *}$

$(0.139)$

$-0.450^{* * * *}$

(0.135)

Yes

$\mathrm{p}=0.000$

0.369

Table 9 offers the counterpart to Table 5, testing whether expectations can be described as purely adaptive. This hypothesis is strongly rejected - sticky-information expectations are much more rational than simple backward-looking adaptive expectations. Again this matches what we observed in the survey data. 
Table 9: Tests of Adaptive Expectations:

Median Inflation Expectations Predicted by the Sticky-information Model

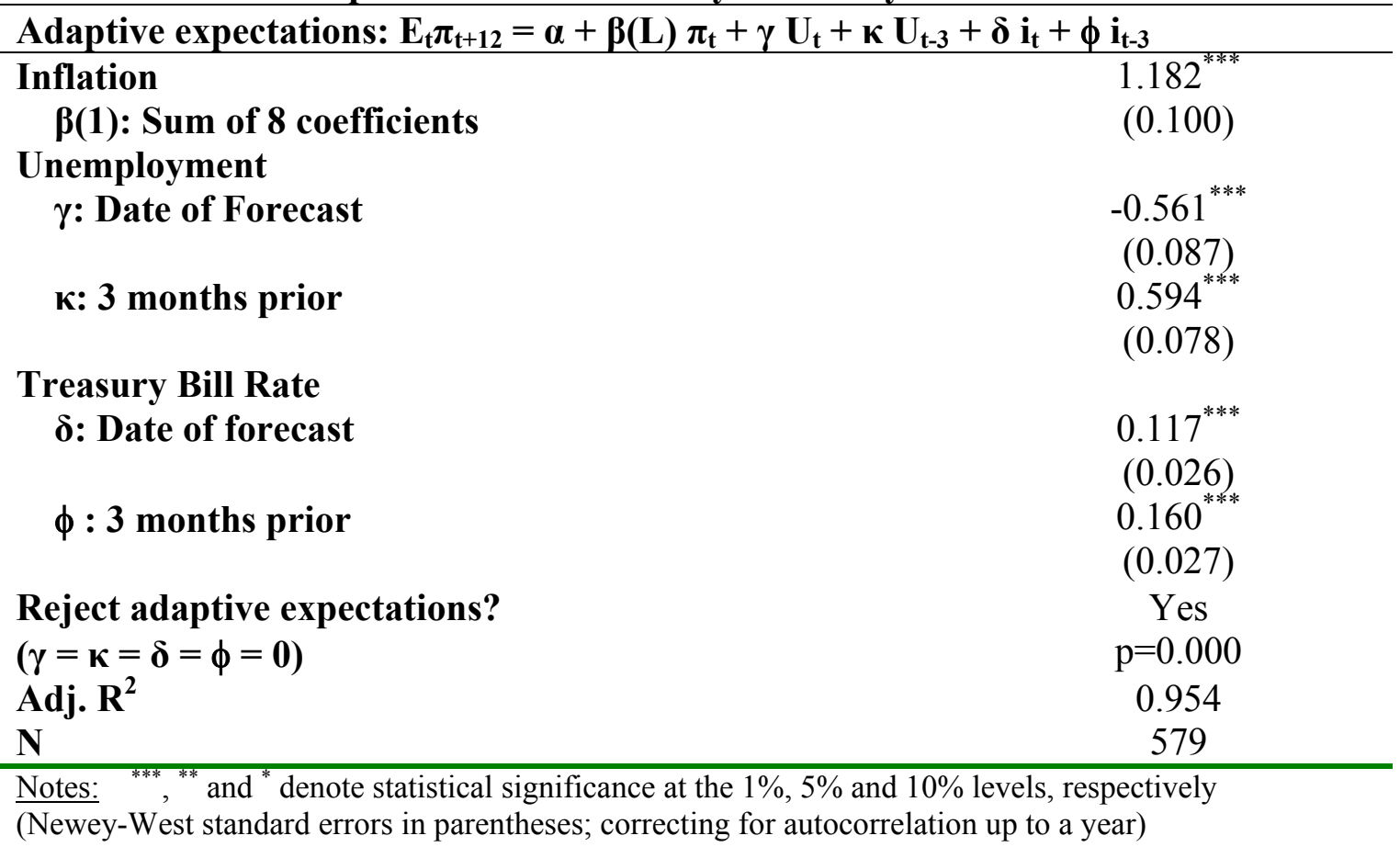

Given how closely the predicted and actual dispersion of expectations and median expected inflation co-move, it is not surprising to find that the results in Tables 4, 5 and 6 are closely matched by the model-generated time series for disagreement in Tables 7,8 and 9. A stronger test in the tradition of moment-matching is to see whether the stickyinformation model can robustly generate the stylized facts we observe in the data. We verify this by implementing the following exercise. Using the residuals from our estimated VAR as an empirical distribution, we randomly draw 720 residual vectors and, using the VAR parameter estimates, use these draws to build hypothetical series for inflation, the output gap, and the Treasury bill rate. We then employ the stickyinformation model to generate a predicted distribution of inflation expectations at each date, using the procedure outlined earlier. To eliminate the influence of initial conditions, 
we discard the initial 10 years of the simulated series, so that we are left with 50 years of simulated data. We repeat this procedure 500 times, thereby generating 500 alternative 50-year histories for inflation, the output gap, the Treasury bill rate, the median expected inflation and the interquartile range of inflation expectations predicted by the stickyinformation model with $\lambda=0.1$. The regressions in Tables 4,5 and 6 , describing the relationship of disagreement and forecast errors with macroeconomic conditions are then re-estimated on each of these 500 possible histories, generating 500 possible estimates for each parameter.

Table 10 reports the mean parameter estimates from each of these 500 histories. Also shown (in parentheses) are the estimates at the $5^{\text {th }}$ and $95^{\text {th }}$ percentile of this distribution of coefficient estimates. We interpret this range as analogous to a bootstrapped $95 \%$ confidence interval (under the null that the sticky-information model accurately describes expectations). These results suggest that the sticky-information model robustly generates a positive relation between the dispersion of inflation expectations and changes in inflation as we observe in the data. Also, as in the data, the level of the output gap appears to be only weakly related to the dispersion of expectations.

Yet, at odds with the facts, the model does not suggest a robust relationship between the level of inflation and the extent of disagreement. To be sure, the relationship suggested in Table 6 does occur in some of these alternative histories, but only in very few. In the sticky-information model, agents only disagree in their forecasts of future inflation to the extent that they have updated their information sets at different points in the past. Given our VAR model of inflation, only changes over time in macroeconomic 
conditions can generate different inflation expectations by different people. The stickyinformation model gives no reason to find a systematic relation between the level of inflation and the extent of disagreement. This does not imply though that for a given history of the world such an association could not exist, and for the constellation of shocks actually observed over the past 50 years this was the case, as can be seen in Table 7. Whether the level of inflation will continue to be related with disagreement is an open question.

Table 10: Model-Generated Disagreement and Macroeconomic Conditions

\begin{tabular}{|c|c|c|}
\hline & $\begin{array}{l}\text { Multivariate } \\
\text { regression }\end{array}$ & $\begin{array}{l}\text { Bivariate } \\
\text { regressions }\end{array}$ \\
\hline \multicolumn{3}{|c|}{ Dependent Variable: Interquartile range of model-generated inflation expectations } \\
\hline Constant & $\begin{array}{c}1.027^{* * * *} \\
(0.612 ; 1.508)\end{array}$ & \\
\hline Inflation Rate & $\begin{array}{c}-0.009 \\
(-0.078 ; 0.061)\end{array}$ & $\begin{array}{c}-0.010 \\
(-0.089 ; 0.071)\end{array}$ \\
\hline$\Delta$ Inflation-squared & $\begin{array}{c}0.029^{* * *} \\
(0.004 ; 0.058)\end{array}$ & $\begin{array}{c}0.030^{* * *} \\
(0.005 ; 0.059)\end{array}$ \\
\hline Output Gap & $\begin{array}{c}-0.019 \\
(-0.137 ; 0.108)\end{array}$ & $\begin{array}{c}-0.023 \\
(-0.163 ; 0.116)\end{array}$ \\
\hline Joint Test on Macro Data & $\begin{array}{l}\text { Reject at } 5 \% \text { level in } \\
98.2 \% \text { of histories }\end{array}$ & \\
\hline Adj. $\mathbf{R}^{2}$ & 0.162 & \\
\hline $\mathbf{N}$ & 588 & 588 \\
\hline
\end{tabular}

Table 11 compares the median of the model-generated inflation expectations series with the artificial series for inflation and the output gap. The results with this simulated data are remarkably similar to those obtained earlier. Panel A shows that expectations are unbiased, although there are many possible histories in which biases (in either direction) of up to a quarter of a percentage point occur. Panel B shows that sticky-information expectations are typically inefficient, while Panel C demonstrates that they induce persistent forecast errors. Panel D shows that sticky-information expectations 
also fail to fully exploit available macroeconomic information, precisely as we found to be true in the survey data on inflation expectations. The precise relation between different pieces of macroeconomic data and expectation errors varies significantly across histories, but in nearly all of them there is a strong relation. Therefore, while the coefficients in Table 11 are not individually significant across histories, within each history a Wald test finds that macroeconomic data is not being fully exploited $78.6 \%$ of the times. That is, the set of macro data that sticky-information agents are found to under-utilize depends on the particular set of shocks in that history. 
Table 11: Tests of Forecast Rationality: Median Inflation Expectations Predicted by the Sticky-information Model over Simulated Histories

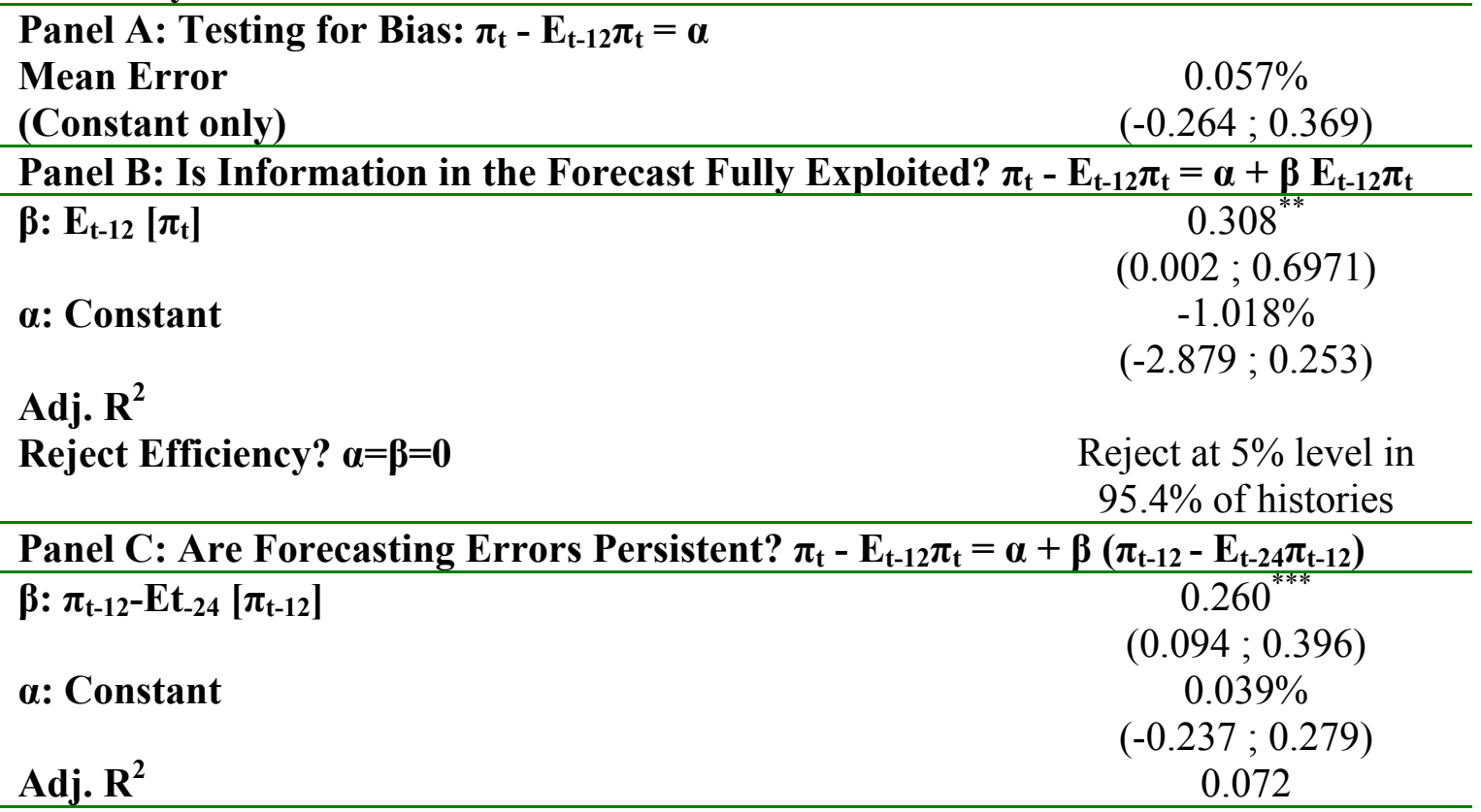

Panel D: Are Macroeconomic data fully exploited? $\pi_{t}-\mathbf{E}_{\mathrm{t}-12} \pi_{\mathrm{t}}=\alpha+\beta \mathbf{E}_{\mathrm{t}-12}\left[\boldsymbol{\pi}_{\mathrm{t}}\right]+\gamma \boldsymbol{\pi}_{\mathrm{t}-13}+\kappa \mathbf{i}_{\mathrm{t}-13}+\delta \mathbf{U}_{\mathrm{t}-13}$

$\alpha:$ Constant

$\beta: \mathbf{E}_{\mathrm{t}-12}\left[\pi_{\mathrm{t}}\right]$

$\gamma:$ Inflation $_{\mathrm{t}-13}$

к: Treasury Bill ${ }_{t-13}$

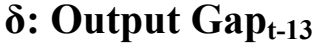

Joint Test on Macro Data $(\gamma=\kappa=\delta=0)$

Adj. $\mathbf{R}^{2}$

$\mathbf{N}$

Notes: ${ }^{* * * *},{ }^{* *}$ and ${ }^{*}$ denote statistical significance at the $1 \%, 5 \%$ and $10 \%$ levels, respectively.

(The $5^{\text {th }}$ and $95^{\text {th }}$ percentile coefficient estimates across 500 alternative histories are shown in parentheses.) . Adj. $\mathrm{R}^{2}$ refers to the average adjusted $\mathrm{R}^{2}$ obtained in the 500 different regressions.

Table 12 tests whether sticky-information expectations could be confused for adaptive expectations in the data. The results strongly reject this possibility. Stickyinformation expectations are significantly influenced by macroeconomic variables (in this 
case, the output gap and the Treasury Bill rate), even after controlling for information contained in past rates of inflation.

Table 12: Tests of Adaptive Expectations: Median Inflation Expectations Predicted by the Sticky-information Model over Simulated Histories

\begin{tabular}{|c|c|}
\hline Adaptive expectations: $\mathrm{E}_{\mathrm{t}-12} \pi_{\mathrm{t}}$ & $i_{t}+\phi i_{t-3}$ \\
\hline Inflation & $1.100^{* *}$ \\
\hline$\beta(1)$ : Sum of 8 coefficients & $(0.177 ; 2.082)$ \\
\hline Output Gap & \\
\hline$\gamma$ : Date of Forecast & $\begin{array}{c}0.380^{* *} \\
(0.064 ; 0.744)\end{array}$ \\
\hline к: 3 months prior & $\begin{array}{c}-0.300 \\
(-0.775 ; 0.190)\end{array}$ \\
\hline Treasury Bill Rate & \\
\hline$\delta:$ Date of forecast & $\begin{array}{c}0.063 \\
(-0.042 ; 0.165)\end{array}$ \\
\hline$\phi: 3$ months prior & $\begin{array}{c}0.149 \\
(-0.111 ; 0.371)\end{array}$ \\
\hline $\begin{array}{l}\text { Reject adaptive expectations? } \\
(\gamma=\kappa=\delta=\phi=0)\end{array}$ & $\begin{array}{c}\text { Reject at } 5 \% \text { level in } \\
100 \% \text { of histories }\end{array}$ \\
\hline Adj. $\mathbf{R}^{2}$ & 0.896 \\
\hline $\mathbf{N}$ & 569 \\
\hline
\end{tabular}

Notes: ${ }^{* * *},{ }^{* *}$ and ${ }^{*}$ denote statistical significance at the $1 \%, 5 \%$ and $10 \%$ levels, respectively.

(The $5^{\text {th }}$ and $95^{\text {th }}$ percentile coefficient estimates across 500 alternative histories are shown in parentheses.) . Adj. $\mathrm{R}^{2}$ refers to the average adjusted $\mathrm{R}^{2}$ obtained in the 500 different regressions.

The sticky-information model does a fairly good job at accounting for the dynamics of inflation expectations that we find in survey data. There is, however, room for improvement. Extensions of the model allowing for more flexible distributions of information arrival hold the promise of an even better fit. An explicit microeconomic foundation for decision-making with information processing costs would likely generate further sharp predictions to be tested with this data. 


\section{A Case Study: The Volcker Disinflation}

In August of 1979, Paul Volcker was appointed chairman of the Board of Governors of the Federal Reserve Board, in the midst of an annual inflation rate of $11 \%$, one of the highest in the post-war United States. Over the next three years, using contractionary monetary policy, he sharply reduced the inflation rate to $4 \%$.

This sudden change in policy and the resulting shock to inflation provides an interesting natural experiment for the study of inflation expectations. The evolution of the distribution of inflation expectations between 1979 and 1982 in the Michigan survey is plotted in figure $12 .{ }^{13}$ For each quarter there were on average 2,350 observations in the Michigan survey, and the frequency distributions are estimated non-parametrically using a normal kernel smoothing function.

\footnotetext{
${ }^{13}$ The Livingston and SPF surveys have too few observations at any given point in time to generate meaningful frequency distributions.
} 
Figure 12: The Volcker Disinflation:

The Evolution of Inflation Expectations in the Michigan Survey

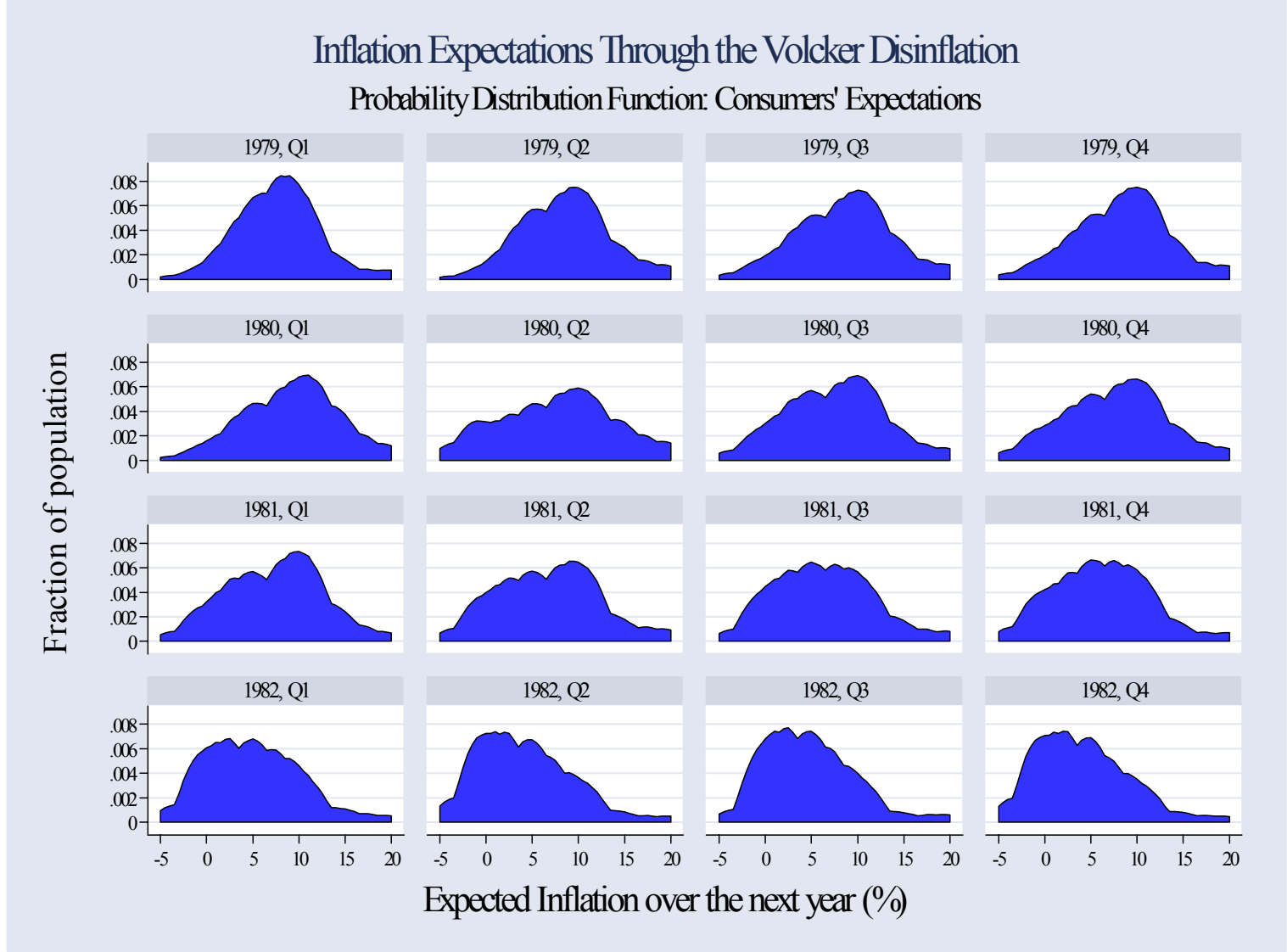

Three features of the evolution of the distribution of inflation expectations stand out from Figure 12. First, expectations adjusted slowly to this change in regime. The distribution of expectations shifts leftwards only gradually over time in the data. Second, in the process, dispersion increases and the distribution flattens out. Third, during the transition, the distribution became approximately bi-modal.

We now turn to asking whether the sticky-information model can account for the evolution of the full distribution of expectations observed in the survey data during this interesting period. Figure 13 plots the distribution of inflation expectations predicted by the VAR application of the sticky-information model described in section V. 
Figure 13: The Volcker Disinflation:

The Evolution of Inflation Expectations Predicted by the Sticky-Information Model

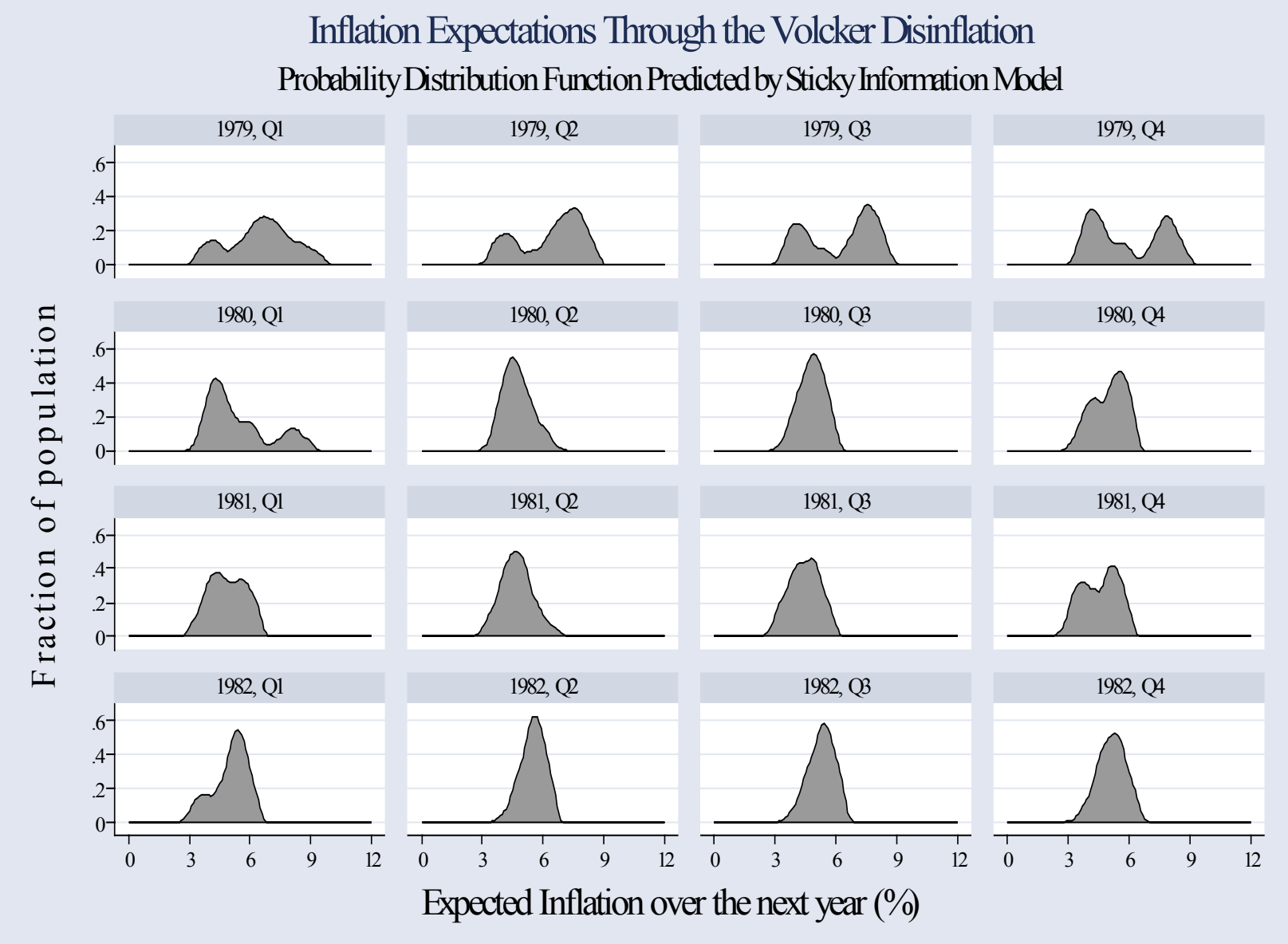

In the sticky-information model, information disseminates slowly throughout the economy. As the disinflation begins, a subset of agents, who have updated their information sets recently, lower their expectation of inflation. As they do so, a mass of the cross-sectional distribution of inflation expectations shifts leftwards. As the disinflation proceeds, a larger fraction of the population revises their expectation of the level of inflation downwards, and thus a larger mass of the distribution shifts to the left. The distribution therefore flattens out and dispersion increases as we observed in the actual data. 
The sudden change in inflation isolates two separate groups in the population. On the one hand, there are those who have recently updated their information sets and are now expecting much lower inflation rates. On the other hand, there remains a group holding to pre-Volcker expectations, giving rise to a bi-modal distribution of inflation expectations. As more agents become informed, a larger mass of this distribution shifts from around the right peak to around the left peak. Ultimately, the distribution resumes its normal single peaked shape, now concentrated at the low observed inflation rate.

Clearly the sticky-information model generates predictions that are "too sharp". Even so, it successfully accounts for the broad features of the evolution of the distribution of inflation expectations during the Volcker disinflation.

\section{CONCLUSION}

Regular attendees of the NBER Macroeconomics Annual conference are well aware of one fact: People often disagree with one another. Indeed, disagreement about the state of the field and the most promising avenues for research may be the conference's most reliable feature. Yet, despite the prevalence of disagreement among conference participants, disagreement is conspicuously absent in the theories being discussed. In most standard macroeconomic models, people share a common information set and form expectations rationally. There is typically little room for people to disagree.

Our goal in this paper is to suggest that disagreement may be a key to macroeconomic dynamics. We believe we have established three facts about inflation 
expectations. First, not everyone has the same expectations. The amount of disagreement is substantial. Second, the amount of disagreement varies over time together with other economic aggregates. Third, the sticky-information model, according to which some people form expectations based on outdated information, seems capable of explaining many features of the observed evolution of both the central tendency and the dispersion of inflation expectations over the past fifty years.

We do not mean to suggest that the sticky-information model explored here is the last word in inflation expectations. The model offers a good starting point. It is surely better at explaining the survey data than are the traditional alternatives of adaptive or rational expectations, which give no room for people to disagree. Nonetheless, the model cannot explain all features of the data, such as the positive association between the level of inflation and the extent of disagreement. The broad lesson from this analysis is clear: If we are fully to understand the dynamics of inflation expectations, we will need to develop of better models of information acquisition and processing. About this, we should all be able to agree. 


\section{REFERENCES}

Ball, Laurence (2000) "Near-Rationality and Inflation in Two Monetary Regimes,” NBER Working Paper 7988.

Ball, Laurence and Dean Croushore (1995) "Expectations and the Effects of Monetary Policy,” NBER Working Paper 5344.

Ball, Laurence, N. Gregory Mankiw and Ricardo Reis (2003) "Monetary Policy for Inattentive Economies," Journal of Monetary Economics, forthcoming.

Barnea A., A. Dotan and Josef Lakonishok (1979) "The Effect of Price Level Uncertainty on the Determination of Nominal Interest Rates: Some Empirical Evidence," Southern Economic Journal.

Brenner, Menachem and Yoram Landskroner (1983) "Inflation Uncertainties and Returns on Bonds," Economica, pp. 463-468.

Bomberger, William and William Frazer (1981) "Interest Rates, Uncertainty and the Livingston Data," Journal of Finance, vol. 36 (3), pp. 661-675.

Bryan, Michael and Stephen Cecchetti (1994) "Measuring Core Inflation," in N. Gregory Mankiw, ed., Monetary Policy, Chicago: University of Chicago Press for NBER.

Bryan, Michael and Guhan Venkatu (2001) "The Curiously Different Inflation Perspectives of Men and Women," Federal Reserve Bank of Cleveland Economic Commentary Series.

Carroll, Christopher (2003a) "Macroeconomic Expectations of Households and Professional Forecasters," Quarterly Journal of Economics, vol. 118 (1), pp. 269-298. 
Carroll, Christopher (2003b) "The Epidemiology of Macroeconomic Expectations," in Larry Blume and Steven Durlauf, eds., The Economy as an Evolving Complex System, III, Oxford University Press, forthcoming.

Croushore, Dean (1993) "Introducing: The Survey of Professional Forecasters," Federal Reserve Bank of Philadelphia, Business Review, November/December, pp. 3-15.

Croushore, Dean (1997) “The Livingston Survey: Still Useful After All These Years," Federal Reserve Bank of Philadelphia, Business Review, March/April, pp. 15-27. Cukierman, Alex and Paul Wachtel (1979) "Differential Inflationary Expectations and the Variability of the Rate of Inflation: Theory and Evidence," American Economic Review, vol. 69 (4), pp. 595-609.

Curtin, Richard (1996) "Procedure to Estimate Price Expectations," mimeo, University of Michigan Survey Research Center.

Friedman, Milton (1968) “The Role of Monetary Policy," American Economic Review, vol. 58 (1), pp. 1-17.

Gavin, William T. (2003) "FOMC Forecasts: Is All the Information in the Central Tendency?" Federal Reserve Bank of St Louis Working Paper 2003-002A.

Juster, F. Thomas and Robert Comment (1978) "A Note on the Measurement of Price Expectations," Institute for Social Research Working Paper, University of Michigan.

Khan, Hashmat and Zhenhua Zhu (2002) "Estimates of the Sticky-Information Phillips Curve for the United States, Canada, and the United Kingdom," Bank of Canada Working paper 2002-19, forthcoming Journal of Money, Credit and Banking. 
Llambros, Louis and Victor Zarnowitz (1987) "Consensus and Uncertainty in Economic Prediction," Journal of Political Economy, vol. 95 (3), pp. 591-62.

Levi, Maurice and John Makin (1979) "Fisher, Phillips, Friedman and the Measured Impact of Inflation on Interest," Journal of Finance, vol. 34 (1), pp. 35-52.

Lucas, Robert E., Jr. (1973) "Some International Evidence on Inflation-Output TradeOffs," American Economic Review, LXIII, pp. 326-334.

Makin, John (1982) "Anticipated Money, Inflation Uncertainty and Real Economic Activity," Review of Economics and Statistics, vol. 64 (1), pp. 126-134.

Makin, John (1983) "Real Interest, Money Surprises, Anticipated Inflation and Fiscal Deficits," Review of Economics and Statistics, vol. 65 (3), pp. 374-384.

Mankiw, N. Gregory and Ricardo Reis (2002) "Sticky Information Versus Sticky Prices: A Proposal to Replace the New Keynesian Phillips Curve," Quarterly Journal of Economics, vol. 117 (4), pp. 1295-1328.

Mankiw, N. Gregory and Ricardo Reis (2003) "Sticky Information: A Model of Monetary Non-neutrality and Structural Slumps," in P. Aghion, R. Frydman, J. Stiglitz, and M. Woodford, eds., Knowledge, Information and Expectations in Modern Macroeconomics: In Honor of Edmund S. Phelps, Princeton University Press.

Mullineaux, Donald (1980) "Inflation Expectations and Money Growth in the United States," American Economic Review, vol. 70 (1), pp. 149-61

Souleles, Nicholas (2001) "Consumer Sentiment: Its Rationality and Usefulness in Forecasting Expenditure - Evidence from the Michigan Micro Data," forthcoming Journal of Money, Credit and Banking. 
Thomas, Lloyd, Jr. (1999) “Survey Measures of Expected U.S. Inflation,” Journal of Economic Perspectives, vol. 13 (4), pp.125-144.

Vissing-Jorgenson, Annette (2003) "Behavioral Finance: An Impartial Assessment or: Does Irrationality Disappear with Wealth? Evidence from Expectations and Actions", NBER Macroeconomics Annual, 2003. 


\section{Appendix: An Experimental Series for the Mean and Standard Deviation of Inflation Expectations in the Michigan survey from 1946 to 2001}

The Michigan Survey of Consumer Expectations and Behavior has been run most quarters since 1946, Q1, and monthly since 1978. The current survey questions have been asked continuously since January 1978 (see Curtin, 1996 for details):

Qualitative: "During the next 12 months, do you think that prices in general will go up, or go down, or stay where they are now?"

Quantitative: "By about what percent do you expect prices to go (up/down) on the average, during the next 12 months?"

For most of the quarterly surveys from June 1966-December 1976, an "open-ended" version of the quantitative question was instead asked as:

Closed: "How large a price increase do you expect? Of course nobody can know for sure, but would you say that a year from now prices will be about 1 or $2 \%$ higher, or $5 \%$, or closer to $10 \%$ higher than now, or what?"

Prior to 1966 , the survey did not probe quantitative expectations at all, asking only the qualitative question. 
Thus, for the full sample period we only have a continuous series of qualitative expectations. Moreover, even the exact coding of this question has varied through time (Juster and Comment, 1978):

- 1948(1)-1952(1): "What do you think will happen to the prices of the things you buy?"

- 1951(4), 1952(2)-1961(1): "What do you expect prices of household items and clothing will do during the next year or so-stay where they are, go up or go down?"

- 1961(2)-1977(2): "Speaking of prices in general, I mean the prices of the things you buy—do you think they will go up in the next year or go down?"

- 1977(3)-Present: "During the next 12 months, do you think that prices in general will go up, or go down, or stay where they are now?"

Lacking a better alternative, we proceed by simply assuming that these different question wordings did not affect survey respondents.

We compile raw data for our experimental series from many different sources:

- 1948(1)-1966(1): Unpublished tabulations put together by Juster and Comment (1978, Table 1).

- 1966(2)-1977(2): Tabulations from Table 2 of Juster and Comment (1978).

- 1967(2), 1977(3)-1977(4): Data were extracted from ICPSR studies \#3619, \#8726 and \#8727, respectively.

- January 1978-August 2001: A large cumulative file containing microdata on all monthly surveys. These data were put together for us by the Survey Research 
Center at the University of Michigan, although most of these data are also accessible through the ICPSR.

These raw data are shown in Figure A.1:

Figure A.1: Qualitative Responses to the Michigan Survey - Long History

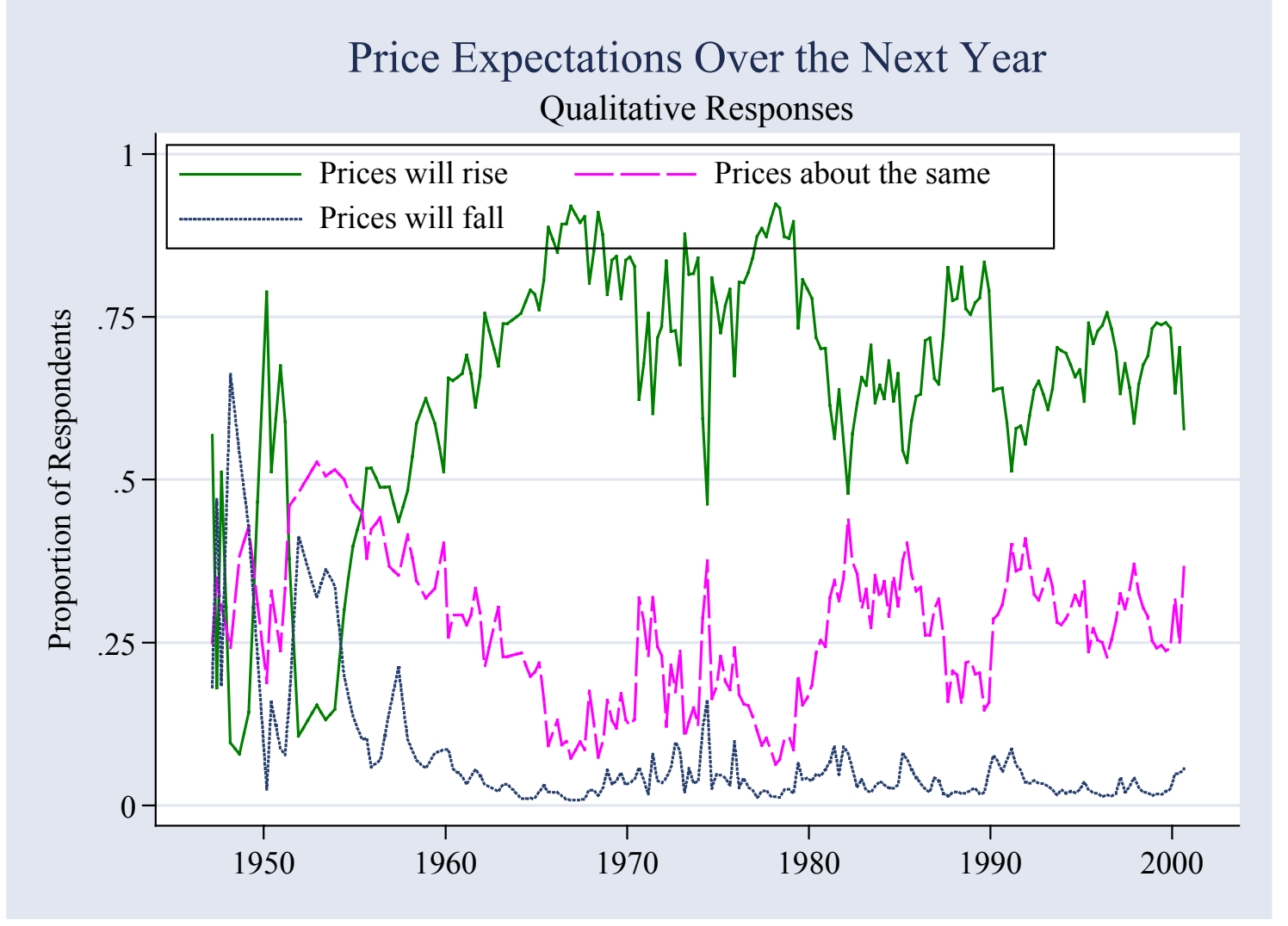

To build a quantitative experimental series from these qualitative data, we make two assumptions. First, note that a relatively large number of respondents expect no change in prices. We should probably not interpret this literally, but rather as revealing that they expect price changes to be "small". We assume that when respondents answer they expect no change in prices, they are stating that expect price changes to be less than some number, $c \%$. Second, we assume that an individual $i$ 's expectation of inflation at time $t$, $\pi_{i t}$, is normally distributed with mean $\mu_{t}$ and standard deviation $\sigma_{t}$. Crucially note that the 
mean and standard deviation of inflation expectations are allowed to shift through time, but that the width of the band around zero for which inflation expectations are described as unchanged shows no intertemporal variation. (That is, there is no time subscript on $c$.)

Consequently, we can express the observed proportions in each category as a function of the cumulative distribution of the standard normal distribution $F_{N}$, the parameter $c$, and the mean and standard deviation of that month's inflation expectations, $\mu_{t}$, and $\sigma_{t}$ :

$$
\begin{aligned}
& \% \text { Down }_{t}=F_{N}\left(\frac{-c-\mu_{t}}{\sigma_{t}}\right) \\
& \% U p_{t}=1-F_{N}\left(\frac{c-\mu_{t}}{\sigma_{t}}\right)
\end{aligned}
$$

Thus, we have two independent data points for each month (\%Same is perfectly collinear with $\% U p+\%$ Down), and we would like to recover two time-varying parameters. The above two expressions can be solved simultaneously to yield:

$$
\begin{aligned}
& \mu_{t}=c\left[\frac{F_{N}^{-1}\left(\% \text { Down }_{t}\right)+F_{N}^{-1}\left(1-\% U p_{t}\right)}{F_{N}^{-1}\left(\% \text { Down }_{t}\right)-F_{N}^{-1}\left(1-\% U p_{t}\right)}\right] \\
& \sigma_{t}=c\left[\frac{2}{F_{N}^{-1}\left(1-\% U p_{t}\right)-F_{N}^{-1}\left(\% \text { Down }_{t}\right)}\right]
\end{aligned}
$$

Not surprisingly, we can recover the time series of the mean and standard deviation of inflation expectations up to a multiplicative parameter, $c$; that is, we can describe the time series of the mean and dispersion of inflation expectations, but the scale is not directly interpretable. To recover a more interpretable scaling, we can either make an ad hoc assumption about the width of the zone from which "same" responses are drawn, or fit some other feature of the data. We follow the second approach and equate the sample mean of the experimental series and the corresponding quantitative estimates of median inflation expectations from the same survey over the shorter 1978-2001 period 
when both quantitative and qualitative data are available. (We denote the median inflation expectation by $\tilde{\pi}.)^{14}$ Formally, this can be stated:

$$
\begin{aligned}
& \sum_{t}^{1978-2001} \mu_{t}=\sum_{t}^{1978-2001} \tilde{\pi}, \text { which solves to yield: } \\
& c=\frac{\sum_{t}^{1978-2001} \tilde{\pi}}{\sum_{t}^{1978-2001} \frac{F_{N}^{-1}\left(\% \text { Down }_{t}\right)+F_{N}^{-1}\left(1-\% U p_{t}\right)}{F_{N}^{-1}\left(\% \text { Down }_{t}\right)-F_{N}^{-1}\left(1-\% U p_{t}\right)}}
\end{aligned}
$$

This assumption yields an estimate of $c=1.7 \%$. That is, the specific scaling adopted yields the intuitively plausible estimate that those expecting inflation between $-1.7 \%$ and $+1.7 \%$, respond that prices will "stay where they are now". More to the point, this specific scaling assumption is not crucial to any of our regression estimates. It affects the interpretation of the magnitude of coefficients, but not the statistical significance.

Thus, for our sample of $\mathrm{T}$ periods, with $2 \mathrm{~T}+1$ parameters and $2 \mathrm{~T}+1$ unknowns, we can estimate the time series of the mean and standard deviation of inflation expectations. As a final step, we rely on the assumption of normality to convert our estimate of the sample standard deviation into an estimate of the interquartile range.

Figures 1 and 3 show that the median and interquartile range of the constructed series moves quite closely with the quantitative estimates over the period from 1978. Table 2 reports on the correlation of this series with other estimates.

\footnotetext{
${ }^{14}$ It is just as valid to refer to the mean of this experimental series as the median expectation, given the assumption of normality.
} 